\title{
動物體內二注入七ラレタル膠樣銅及ビ 有機銅化合物ノ分布並二排泄二就广
}

\author{
矢野 沗 芳 \\ (京都帝國大學醫學部蓕物學敉空〔荻生教授〕) \\ （昭和十三年一月二十八日受付）
}

\section{緒官}

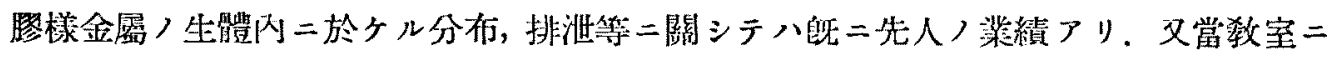

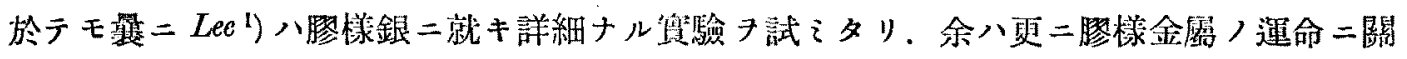

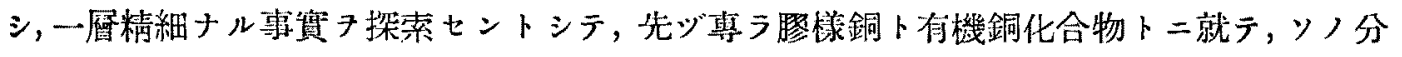
仰, 排泄ノ狀態子比較セント欲スルモノナリ。

凡ソ，生物界二於ヶル銅ノ分布ハ久シキ以前ヨり認メラレタル事惯ナレドモ，ソノ存 在ニ關シテハ近時マラ゙動植物ノ存在二對シ從屬的ナル意義タ有スルモ，ト見做サレタリ。

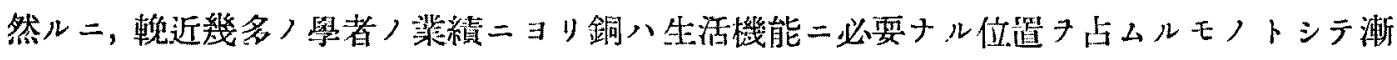
ク學界/注目スル所トナレリ，抑タ，Buchholtz u. Meissner ${ }^{2}$ )ガ初メテ植物性二銅ノ存在 明白二せシ以來, 動物界二於テモ諸學者，研究ニヨリ, 銅八㑔體動物，大部分，節足動物， 一部，血夜中二於テ恰モ脊椎動物血液，Haemoglobin二相嫦スべキ Haemocyaninナルー 種ノ蛋白銅ノ形二於テ存在シ,コノモノ八生體內二於ケル酸化機轉二對シ重要ナル意義タ 有スルエノト結諭セラレタリ $\left(\right.$ Cotwell $\left.^{3}\right)$, Meyerhof u. Matsuoka $\left.{ }^{4}\right)$, Severy u. Hazel $\left.{ }^{5}\right)$, Krebs $\left.{ }^{6}\right)$, 進》等].

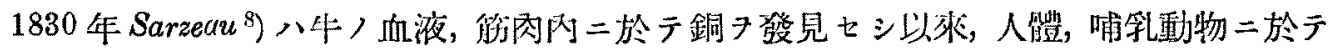

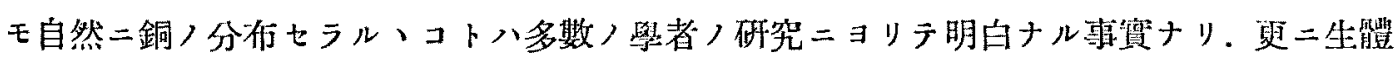

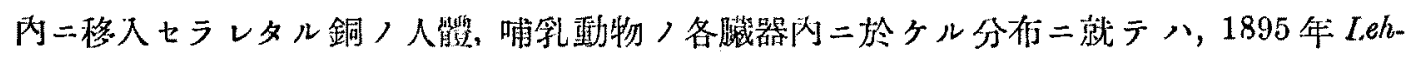

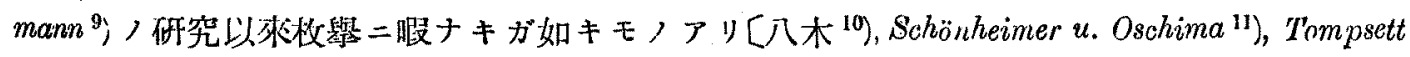

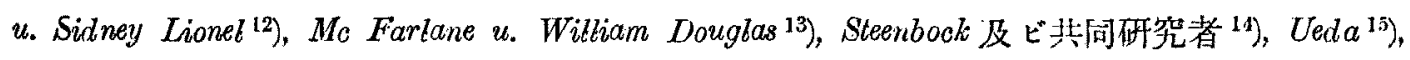
Sugihara $\left.{ }^{16}\right)$, Flinn $u$. Inoue ${ }^{17}$ 等].

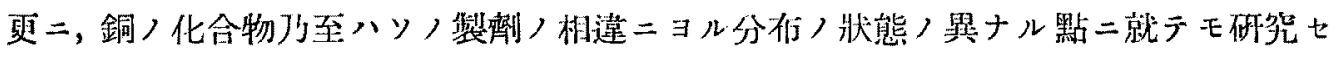




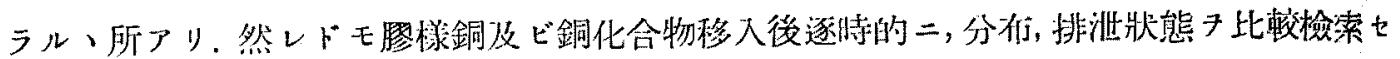
ルモノニ至リデハ案聞多フ知ラズ.

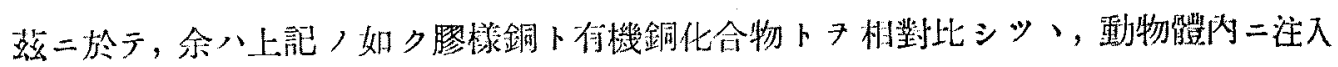

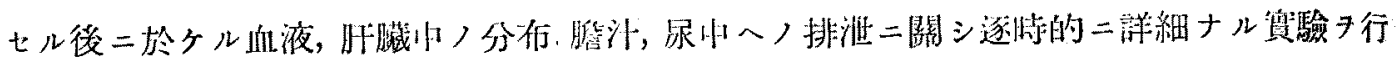
ヒタリ。

\section{實驗材料及ビ實驗方法}

惯騟動物トシテハ，一定條件下二飼育セル健康ナル雄性 Ratte 及ピ家鬼

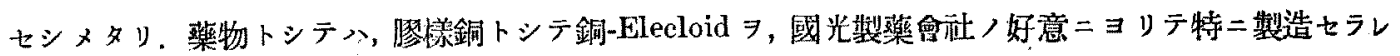

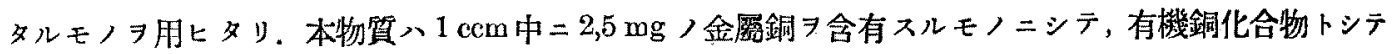

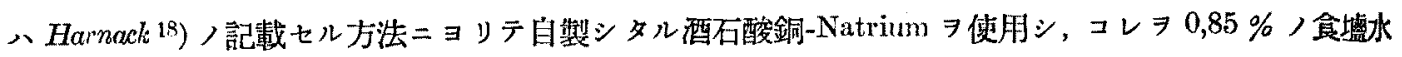

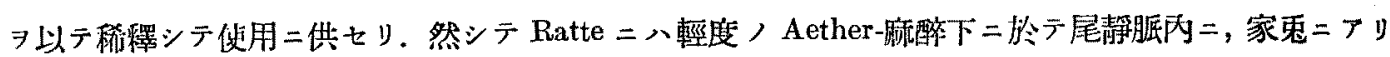

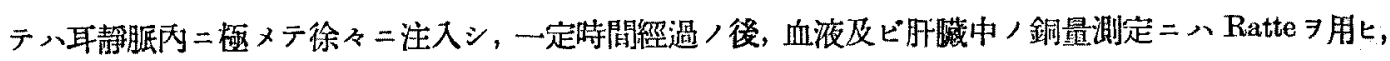

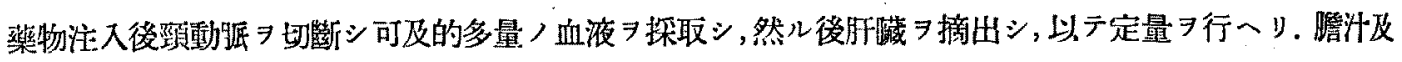

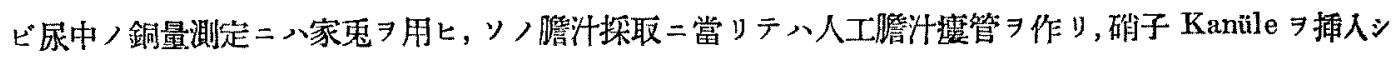

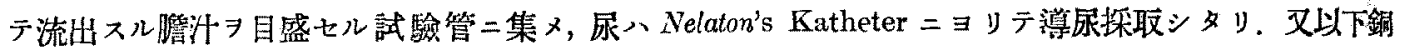

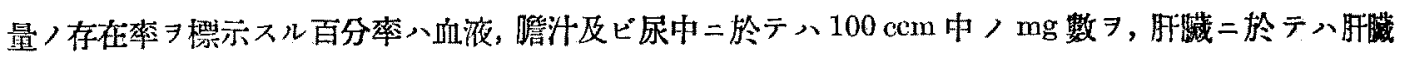
物質 $100 \mathrm{~g}$ 中ノ $\mathrm{mg}$ 數ヨ示スモノナリ.

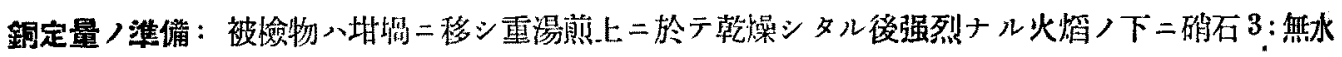
炭酸-Natrium 1 ヨ混合シタルモ， ヨ加へテ完全二灰化シ，冷却シタル後 $3-5 \mathrm{ccm} /$ 稀硝酸 7 加へテ熱

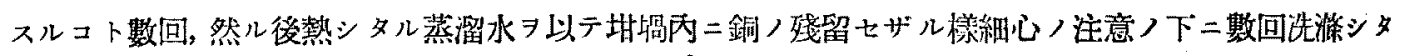

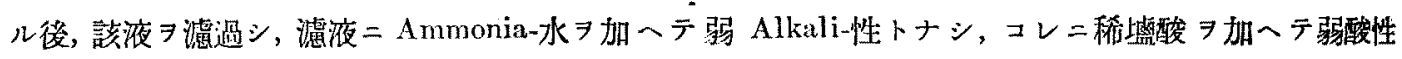

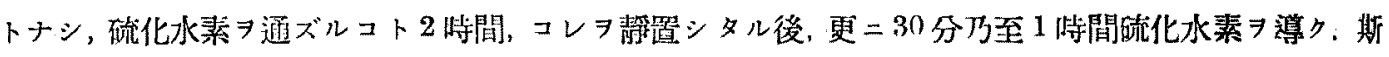

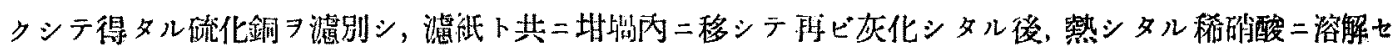

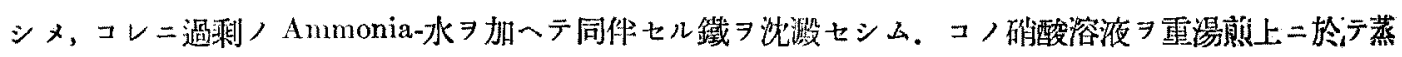

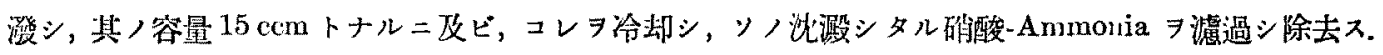

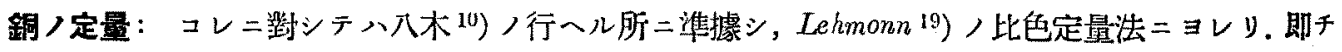
上記八溶液 7 試驗管二移シ $1 \mathrm{~cm}$ ，Ammonia-水 7 添加ス.被檢液 $0,2 \mathrm{mg}$ 以上ノ銅 7 含有スルトキ八青

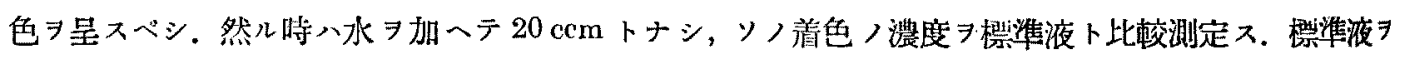

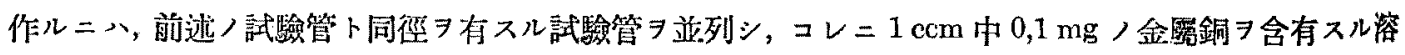

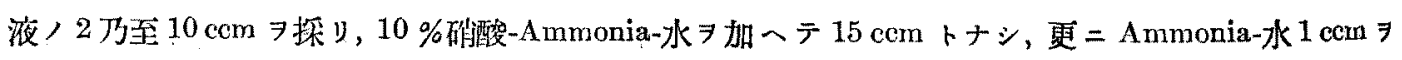
加フ. 然儿時八種々ノ濃度

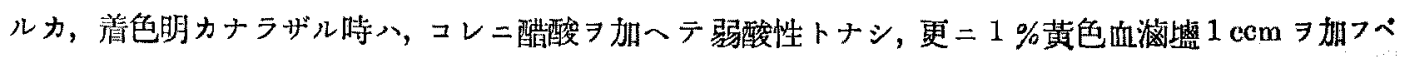

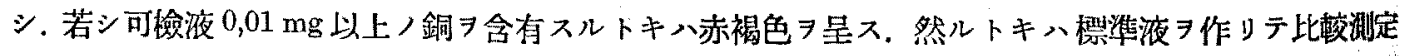

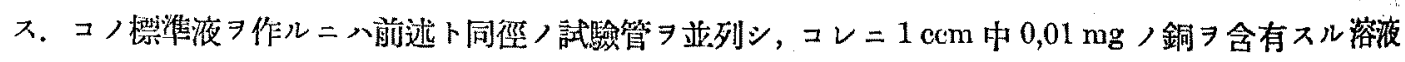

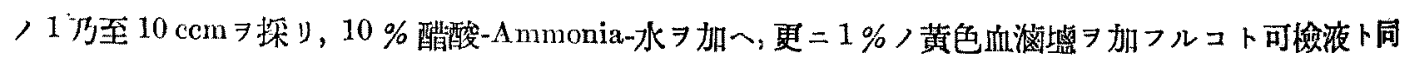

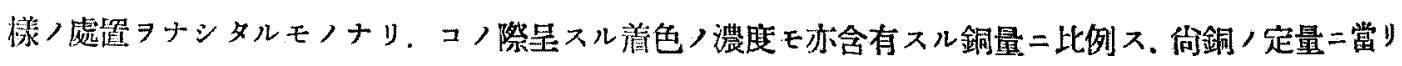




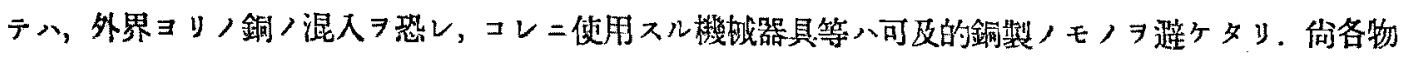
質中ノ銅量二就テハ檢索ニョリテ得タル值ヨリ，余ガ正常動物二於テ登明シ得タル平均銅量 テ, 銅注入後二於ヶル分布量ト見做さリ。

\section{實 驗 成 綪}

\section{1. 膠樣銅並二有機銅化合物 䓯性ニ就テ}

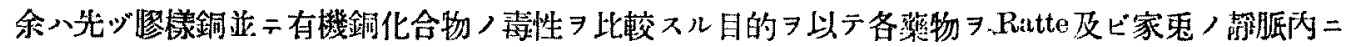

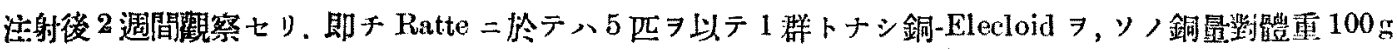
$=0,5 \mathrm{mg} \Rightarrow$ 尾静质內二注入シタル場合二於テハ, 注入後然洔ニシテ試獸八毛 7 逆立テ胴

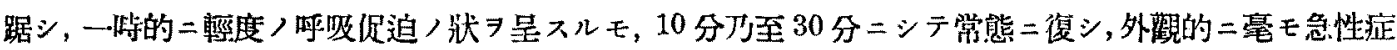

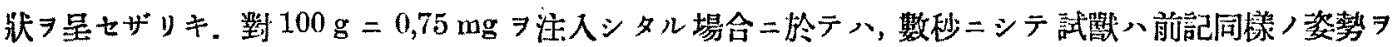
ナシ呼吸速迫，心悸元進現ハレ催吐樣開口運動 ナナシ, 30 分乃至 1 洔間二於テ目 7 閉ジ運動暒鈍トナリ，

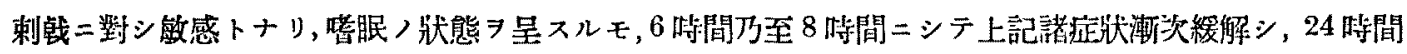

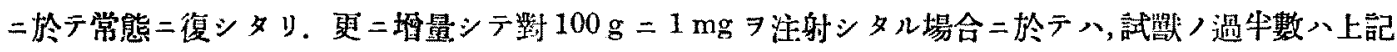

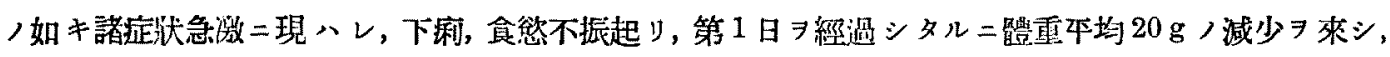

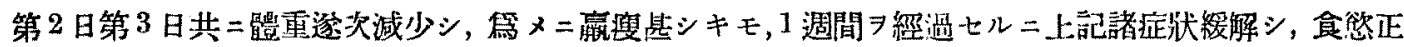

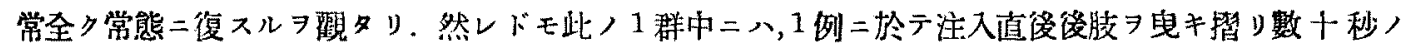

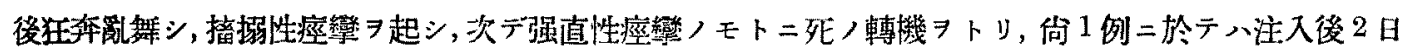

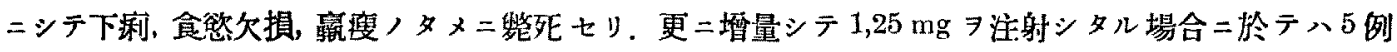

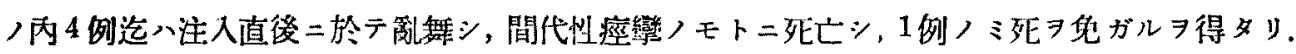

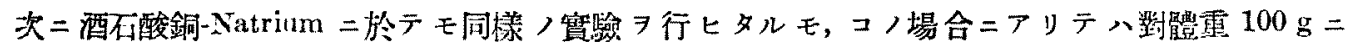

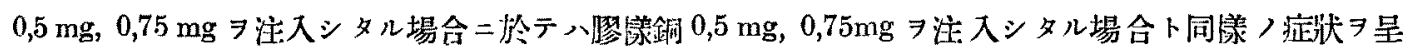

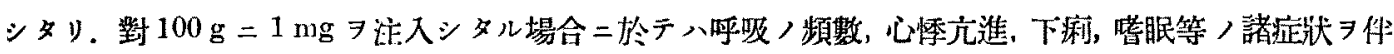

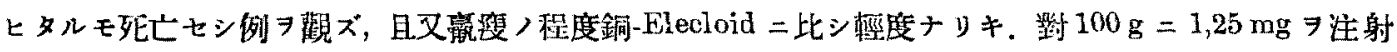

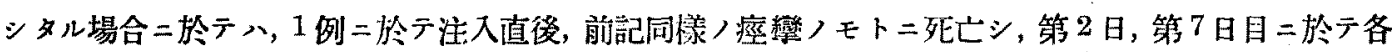

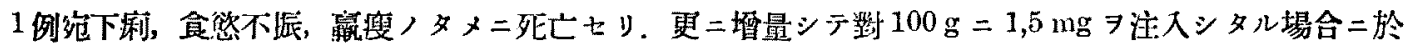
テハ注入直後二於テ 4 例死亡シ, 第 1 日目 $=$ 於テ更 $=1$ 例死亡七リ。

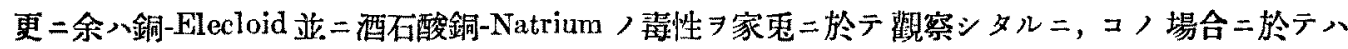

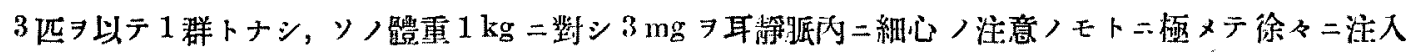

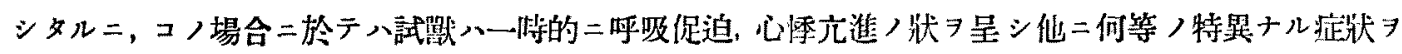

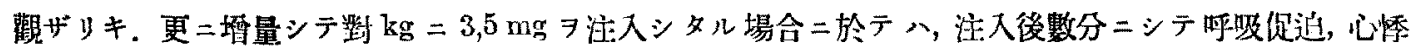

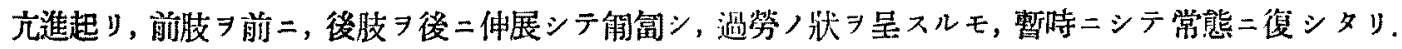

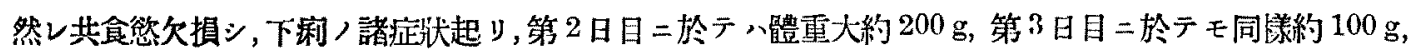

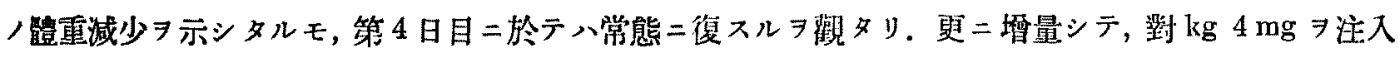

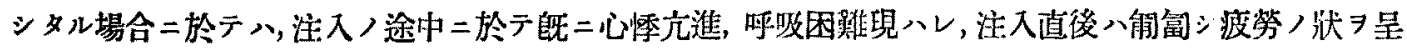
スルモ數十分後二於テ運動 $\ni$ 始メタリ。然シテ第 1 日目，第 2 日日二於テハ下痢，食箵欠損甚シク，タ

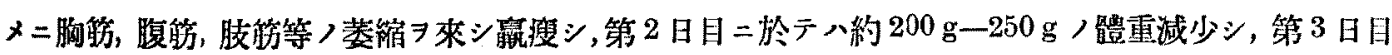


ニ於テ八更二約 $100 \mathrm{~g}-120 \mathrm{~g}$ 體重減少シタルモ，第 4 日目二至リテ漸次常態二復スルニ至レリ。然レ

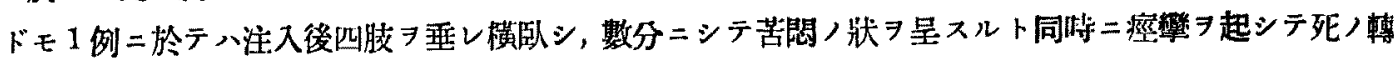

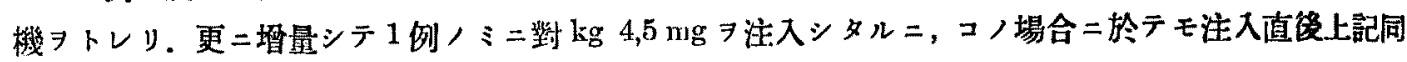
樣ノ諸症狀急激二起り死亡スル 觀タリ.

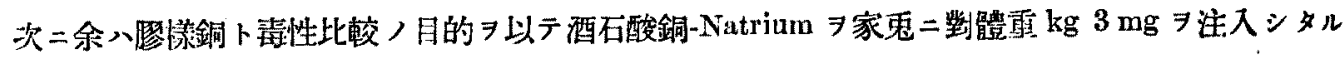

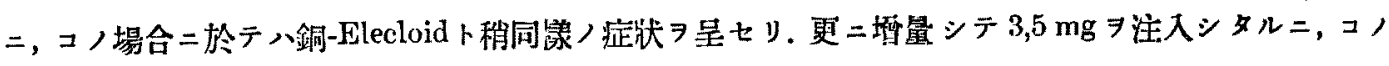

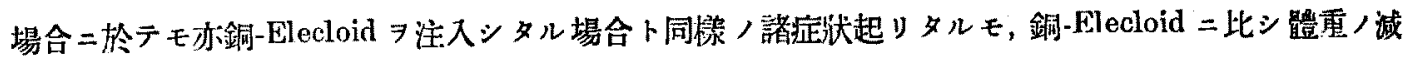

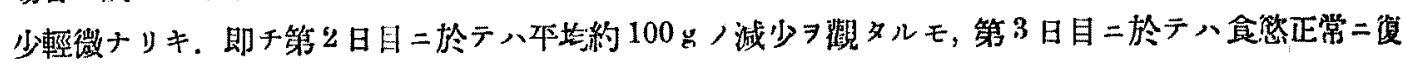

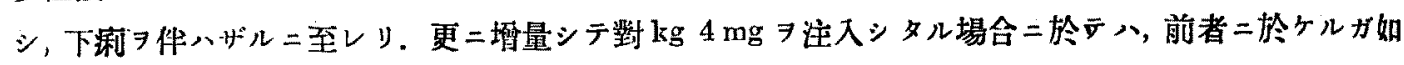

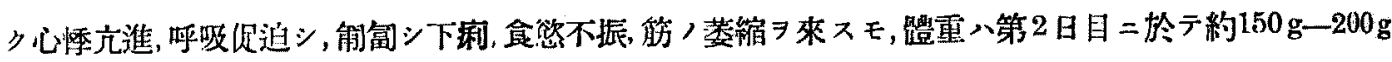
減少シ，第 3 日目二於テハ大約 $50 \mathrm{~g}$ ノ隇少ヨ示シタルモ，第 4 日目二於テハ全》正常二复シタリ. 倘此

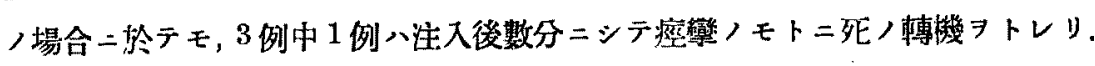

即于銅-Elecloid 並二酒石酸銅-Natrium 八, Ratte 及ビ家來二坽テ相似タル中毒症状ヨ呈シ，Ratte

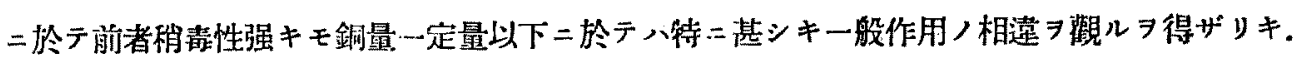

\section{2. 正常ナル Ratte ノ血液, 肝歲及ビ家鬼腺汁中ノ銅含有量}

試獸八何レモ一定终件下二飼育シ，使用前 24 時間絕食セシメタル健康ナル雄性ノモノヨ選ビタリ。 本测定二際シテ八, 元來测定スベキ銅量微量ニシテ, 各動物二就テノ成績ハ不正礁ナル

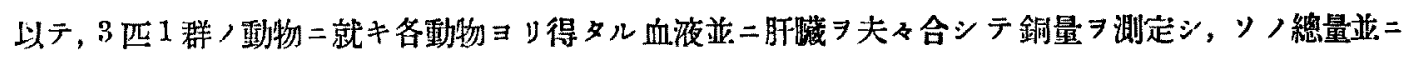

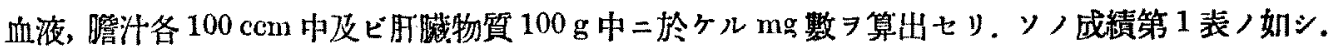

茀 1 表. a. 正常 Ratte /血液並=畈臟中，銅含有最.

\begin{tabular}{|c|c|c|c|c|c|c|c|}
\hline \multirow{2}{*}{$\begin{array}{l}\text { Ratte } \\
\text { 番 號 }\end{array}$} & \multirow{2}{*}{ 體 重 } & \multirow{2}{*}{$\begin{array}{c}\text { 挆 血 量 } \\
\text { (ccm) }\end{array}$} & \multirow{2}{*}{$\begin{array}{c}\text { 肝臟重量 } \\
(\mathrm{g})\end{array}$} & \multicolumn{2}{|c|}{ 血液中／检出銅量 } & \multicolumn{2}{|c|}{ 肝臟中／檢出銅暴 } \\
\hline & & & & $\begin{array}{c}\text { 絕 對 量 } \\
(\mathrm{mg})\end{array}$ & $\mathrm{mg} \%$ & $\begin{array}{c}\text { 絶 龊 量 } \\
(\mathrm{mg})\end{array}$ & $\mathrm{mg} \%$ \\
\hline I & 230 & 6,0 & 5,6 & & & & \\
\hline II & 170 & 5,0 & 4,6 & & & & \\
\hline III & 180 & 5,5 & 5,0 & & & & \\
\hline 㮩 量 & & 16.5 & 15,2 & 0,02 & 0,12 & 0,12 & 0,79 \\
\hline IV & 220 & 6,0 & 5,5 & & & & \\
\hline $\mathrm{V}$ & 185 & 5,5 & 4,5 & & & & \\
\hline VI & 190 & 5,0 & 4,8 & & & & \\
\hline 總 量 & & 16,5 & 14.8 & 0,03 & 0,18 & 0,09 & 0,61 \\
\hline VII & 165 & 5,4 & 5,4 & & & & \\
\hline VIII & 170 & 5,3 & 6,6 & & & & \\
\hline IX & 160 & 5,4 & 5,7 & & & & \\
\hline 總 擂 & & 16,1 & 17,7 & 0,02 & 0,12 & 0,08 & 0,45 \\
\hline 平均 & & & & & 0,14 & & 0,62 \\
\hline
\end{tabular}




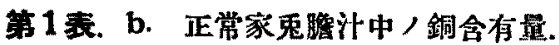

\begin{tabular}{|c|c|c|c|c|}
\hline 家鬼番號 & $\begin{array}{c}(\mathrm{c}) \\
\end{array}$ & 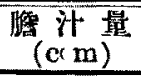 & $\begin{array}{c}\text { 絕 對 } \\
\text { (mg) }\end{array}$ & $\mathbf{m g} \%$ \\
\hline I & 2150 & 25 & 0,04 & 0,16 \\
\hline II & 2300 & 30 & 0,06 & 0,20 \\
\hline III & 2520 & 40 & 0,07 & 0,178 \\
\hline 平均 & & & & 0,18 \\
\hline
\end{tabular}

即千正常 Ratte／血液中=含有セラルル銅量八 $0,12 \mathrm{mg} \%-0,18 \mathrm{mg} \%$ 平均 $0,14 \mathrm{mg} \%$, 肝藏中二於

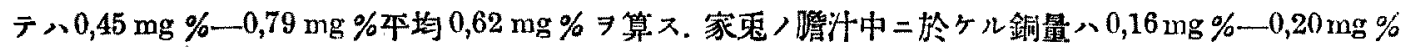
平均 $0,18 \mathrm{mg} \% \ni$ 證明七り.

\section{3. 銅-Elecloid $\ni$ Ratte / 尾靜胍內ニ注入シタル後ニ於ケル 血液, 肝镜中/銅含有量}

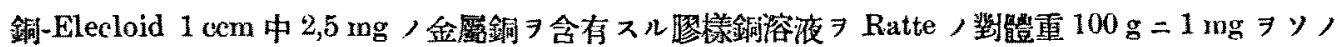

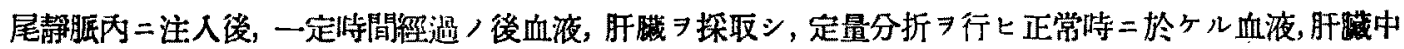
，銅量 ヨ控除シタル結果次ノ如キ成績

第 2 表. 銅-Elecloid $\Rightarrow$ Ratte，静脈內二注入ンタ几後二於ケル血液亚二肝臟中， 銅含有量 注入銅量對 $100 \mathrm{~g} 0,4 \mathrm{ccm}$ (含有銅量 $1 \mathrm{mg}$ ).

\begin{tabular}{|c|c|c|c|c|c|c|c|c|c|}
\hline \multirow{2}{*}{$\begin{array}{l}\text { 注射後 } \\
\text { 縃渦時間 }\end{array}$} & \multirow{2}{*}{$\begin{array}{l}\text { Ratte } \\
\text { 番 號 }\end{array}$} & \multirow{2}{*}{$\begin{array}{c}\text { Ratte } \\
\text { 脿 重 } \\
\text { g) }\end{array}$} & \multirow{2}{*}{$\mid \begin{array}{c}\text { 注 射量 } \\
\left(\begin{array}{c}\text { 對動物意) } \\
(\mathrm{ccm})\end{array}\right.\end{array}$} & \multirow[b]{2}{*}{$\begin{array}{l}\text { 探血量 } \\
(\mathrm{ccm})\end{array}$} & \multicolumn{2}{|c|}{ 血液中，檢出銅量 } & \multirow[b]{2}{*}{$\begin{array}{c}\text { 质臟重量 } \\
(\mathrm{g})\end{array}$} & \multicolumn{2}{|c|}{ 肝腿中ノ檢仙銅量 } \\
\hline & & & & & 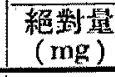 & Ing \% & & 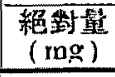 & $\mathrm{mg} \%$ \\
\hline \multirow{4}{*}{10 分 } & I & 190 & 0,76 & 5,5 & 0,192 & 3,491 & 7,8 & 0,032 & 0,410 \\
\hline & II & 185 & 0,74 & 6,0 & 0,212 & 3,533 & 6,0 & 0,033 & 0,550 \\
\hline & III & 160 & 0,64 & 4,0 & 0,144 & 3,600 & 5,5 & 0,036 & 0,655 \\
\hline & 平均 & & 0,71 & 5,2 & 0,183 & 3,541 & 6,4 & 0,034 & 0,538 \\
\hline \multirow{4}{*}{1 時間 } & IV & 205 & 0,82 & 5,0 & 0,143 & 2,860 & 6,0 & 0,093 & 1,550 \\
\hline & $\mathrm{V}$ & 205 & 0,82 & 5,0 & 0,143 & 2,860 & 7,3 & 0,136 & 1,863 \\
\hline & VI & 175 & 0,70 & 4,5 & 0,124 & 2,755 & 6,3 & 0,101 & 1,603 \\
\hline & 平 均 & & 0,78 & 4,8 & 0,137 & 2,825 & 6,5 & 0,110 & 1,672 \\
\hline \multirow{4}{*}{2 時間 } & VII & 185 & 0,74 & 4,1 & 0,124 & 3,024 & 5,8 & 0,114 & 1,966 \\
\hline & VIII & 200 & 0,80 & 5,0 & 0,113 & 2,260 & 7,5 & 0,133 & 1,773 \\
\hline & $I X$ & 145 & 0,58 & 4,1 & 0,094 & 2,293 & 5,0 & 0,119 & 2,380 \\
\hline & 平 均 & & 0,71 & 4,4 & 0,110 & 2,526 & 6,3 & 0,122 & 2,039 \\
\hline \multirow{4}{*}{4 時間 } & $\mathrm{x}$ & 170 & 0,68 & 4,6 & 0,054 & 1,174 & 5,1 & 0,118 & 2,314 \\
\hline & XI & 180 & 0,72 & 4,0 & 0,055 & 1,875 & 4,7 & 0,151 & 3,213 \\
\hline & XII & 160 & 0,64 & 4,8 & 0,064 & 1,333 & 4,2 & 0,124 & 2,952 \\
\hline & 平 均 & & 0,68 & 4,5 & 0,058 & 1,294 & 4,7 & 0,131 & 2,826 \\
\hline
\end{tabular}




\begin{tabular}{|c|c|c|c|c|c|c|c|c|c|}
\hline \multirow{2}{*}{$\begin{array}{l}\text { 注射後， } \\
\text { 經過洔間 }\end{array}$} & \multirow{2}{*}{$\begin{array}{l}\text { Ratte' } \\
\text { 番 號 }\end{array}$} & \multirow{2}{*}{$\begin{array}{l}\text { Ratte / } \\
\text { 骴 重 } \\
\text { (g) }\end{array}$} & \multirow{2}{*}{$\begin{array}{c}\text { 洼射 量 } \\
\text { (龇動物) } \\
\text { (ccm) }\end{array}$} & \multirow[b]{2}{*}{$\begin{array}{l}\text { 珻血量 } \\
(\mathrm{ccm})\end{array}$} & \multicolumn{2}{|c|}{ 血液中，检出銅量 } & \multirow[b]{2}{*}{ 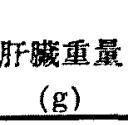 } & \multicolumn{2}{|c|}{ 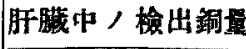 } \\
\hline & & & & & $\begin{array}{l}\text { 絕数鼠 } \\
(\mathrm{mg})\end{array}$ & $\mathrm{mg} \%$ & & 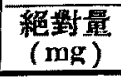 & ing \% \\
\hline \multirow{4}{*}{6 時間 } & XIII & 130 & 0,52 & 4,5 & 0,054 & 1,200 & 4,5 & 0,152 & 3,378 \\
\hline & XIV & 175 & 0,70 & 4,8 & 0,053 & 1,104 & 5,6 & 0,165 & 2,946 \\
\hline & XV & 175 & 0,70 & 2,8 & 0,036 & 1,286 & 4,8 & 0,120 & 2,500 \\
\hline & 平 均 & & 0,64 & 4,0 & 0,048 & 1,197 & 5,0 & 0,146 & 2,941 \\
\hline \multirow{4}{*}{8 時閏 } & $\mathrm{XVI}$ & 180 & 0,72 & 4,7 & 0,048 & 0,914 & 4,9 & 0,170 & 3,469 \\
\hline & XVIJ & 195 & 0,78 & 4,4 & 0,034 & 0,773 & 4,7 & 0,151 & 3,213 \\
\hline & XVIII & 195 & 0,78 & 4,4 & 0,044 & 1,000 & 4,6 & 0,152 & 3,364 \\
\hline & 平 均 & & 0,76 & 4,5 & $0, \mathrm{C} A 1$ & 0,896 & 4,7 & 0,158 & 3,329 \\
\hline \multirow{4}{*}{10 時間 } & XIX & 175 & 0,70 & 4,5 & 0,034 & 0,756 & 5,6 & 0,155 & 2,946 \\
\hline & $\mathrm{xX}$ & 145 & 0,58 & 4,5 & 0,024 & 0,533 & 5,0 & 0,120 & 2,400 \\
\hline & $\mathrm{XXI}$ & 160 & 0,64 & 4,6 & 0,024 & 0,522 & 4,2 & 0,124 & 2,952 \\
\hline & 本 均 & & 0,64 & 4,5 & 0,027 & 0,604 & 4,9 & 0,136 & 2,766 \\
\hline \multirow{4}{*}{24 時間 } & XXII & 170 & 0,68 & 4,0 & - & - & 4,9 & 0,120 & 2,449 \\
\hline & XXIII & 140 & 0,56 & 4,0 & 0,014 & 0,350 & 5,3 & 0,117 & 2,208 \\
\hline & XXIV & 190 & 0,76 & 4,2 & - & - & 6,0 & 0,143 & 2,383 \\
\hline & 本均 & & 0,67 & 4,1 & ? & $?$ & 5,4 & 0,127 & 2,346 \\
\hline \multirow{4}{*}{48 洔閠 } & $X X V$ & 145 & 0,58 & 3,3 & - & $?$ & 4,5 & 0,092 & 2,044 \\
\hline & XXVI & 170 & 0,68 & 4,7 & - & $?$ & 6,4 & 0,090 & 1,406 \\
\hline & XXVII & 225 & 0,90 & 5,7 & - & $?$ & 6,7 & 0,138 & 2,060 \\
\hline & 平 均 & & 0,72 & 4,6 & & & 5,9 & 0,107 & 1,837 \\
\hline \multirow{4}{*}{144 洔間 } & XXVIII & 170 & 0,68 & & & & 3,8 & 0,026 & 0,684 \\
\hline & $\mathrm{XXIX}$ & 175 & 0,70 & & & & 4,2 & 0,024 & 0,571 \\
\hline & $\mathrm{xxx}$ & 180 & 0,72 & & & & 3,2 & 0,020 & 0,625 \\
\hline & 平 均 & & 0,70 & & & & 3,7 & 0,023 & 0,627 \\
\hline \multirow{4}{*}{336 洔間 } & XXXI & 210 & 0,84 & & & & 8,8 & 0,005 & 0,057 \\
\hline & XXXII & 180 & 0,72 & & & & 5,3 & - & ? \\
\hline & XXXIII & 200 & 0,80 & & & & 7,3 & - & $?$ \\
\hline & 平 均 & & 0,79 & & & & 7,1 & $?$ & $?$ \\
\hline
\end{tabular}

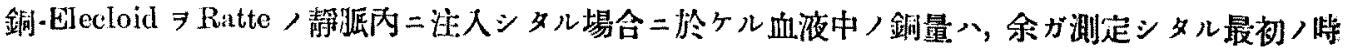
間, 即于 10 分後二於テ八平均 $3,541 \mathrm{mg} \%, 1$ 時間後二於テハ本均 $2,825 \mathrm{mg} \%, 2$ 時間後二於テ八本均 $2,526 \mathrm{mg} \%, 4$ 洔間後二於テハソ八大部分 7 沙失シ, $1,294 \mathrm{mg} \% 7$ 示シ, 爾後八極メテ徐々二減少シ，

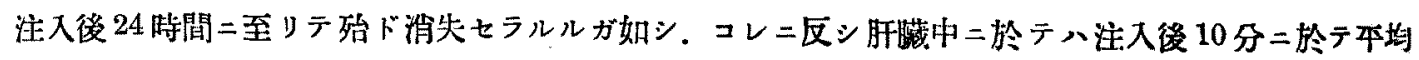
$0,538 \mathrm{mg} \%, 1$ 時間後二於テ 、平均 $1,672 \mathrm{mg} \%, 2$ 峙間後二於テ 八平均 $2,309 \mathrm{mg} \%, 4$ 洔間後二於テ 八本 均 $2,826 \mathrm{mg} \%, 6$ 洔間後二於テ 、平均 $2,941 \mathrm{mg} \%, 8$ 時間後二至リテハソノ銅量最モ多っ 位均 $3,329 \mathrm{mg} \%$ 7示シ, 爾後嫁次減少シ, 全ク消失スルニ八大約 2 週間 7 要スルモノノ如シ (第 2 表參照). 


\section{4. 酒石酸銅-Natrium $\ni$ Ratte／尾靜胍內二注入シタル後ニ於ケル 血液、肝臟中/銅含有量}

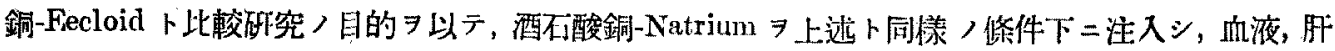
贜中ノ銅量 7 測定シタル處次ノ如キ成績 7 得タリ (第 3 表參照).

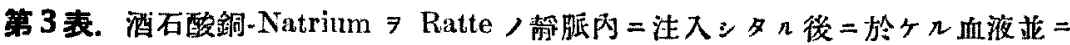

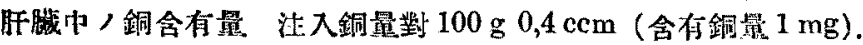

\begin{tabular}{|c|c|c|c|c|c|c|c|c|c|}
\hline \multirow{2}{*}{$\begin{array}{l}\text { 注射後， } \\
\text { 䔣過時間 }\end{array}$} & \multirow{2}{*}{$\begin{array}{l}\text { Rutte } \\
\text { 番 虎 }\end{array}$} & \multirow{2}{*}{$\begin{array}{c}\text { Ratte } \\
\text { 體 重 } \\
(\mathrm{g})\end{array}$} & \multirow{2}{*}{ 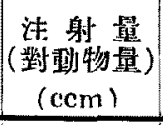 } & \multirow[b]{2}{*}{$\begin{array}{l}\text { 陉血量 } \\
(\mathrm{ccm})\end{array}$} & \multicolumn{2}{|c|}{ 血液中，檢出銅量 } & \multirow[b]{2}{*}{$\begin{array}{c}\text { 肝臟重量 } \\
(\mathrm{g})\end{array}$} & \multicolumn{2}{|c|}{ 肝输中，檢出銅量 } \\
\hline & & & & & $\begin{array}{c}\text { 絕数量 } \\
\mathrm{mg})\end{array}$ & $\mathrm{mg} \%$ & & \begin{tabular}{|l|} 
總䝰量 \\
(mg)
\end{tabular} & $m g \%$ \\
\hline \multirow{4}{*}{10 分 } & $I$ & 195 & 0,78 & 7,5 & 0,239 & 3,187 & 6,1 & 0,032 & 0,525 \\
\hline & II & 160 & 0,64 & 5,5 & 0,192 & 3,491 & 7,3 & 0,035 & 0,479 \\
\hline & III & 130 & 0,52 & 4,5 & 0,194 & 4,311 & 5,5 & 0,026 & 0,473 \\
\hline & 平 均 & & 0,65 & 5,8 & 0,208 & 3,663 & 6,3 & 0,031 & 0,492 \\
\hline \multirow{4}{*}{1 筝間 } & IV & 130 & 0,52 & 5,0 & 0,143 & 2,860 & 5,3 & 0,147 & 2,774 \\
\hline & V & 140 & 0,56 & 4,0 & 0,114 & 2,850 & 6,3 & 0,151 & 2,397 \\
\hline & VI & 190 & 0,76 & 4,5 & 0,144 & 3,200 & 7,5 & 0,203 & 2,707 \\
\hline & 平 均 & & 0,61 & 4,5 & 0,134 & 2,970 & 6,4 & 0,167 & 2,626 \\
\hline \multirow{4}{*}{2 洔間 } & VII & 180 & 0,72 & 4,0 & 0,064 & 1,600 & 6,5 & 0,140 & 2,154 \\
\hline & VIII & 115 & 0,46 & 4,0 & 0,064 & 1,600 & 4,2 & 0,090 & 2,238 \\
\hline & IX & 175 & 0,70 & 5,0 & 0,083 & 1,660 & 6,5 & 0,140 & 2,154 \\
\hline & 平 均 & & 0,63 & 4,3 & 0,070 & 1,620 & 5,7 & 0,125 & 2,182 \\
\hline \multirow{4}{*}{4 洔開 } & $\mathrm{X}$ & 135 & 0,54 & 5,0 & 0,063 & 1,260 & 3,8 & 0,076 & 2,000 \\
\hline & $\mathrm{XI}$ & 175 & 0,70 & 4,5 & 0,044 & 0,978 & 6,0 & 0,113 & 1,883 \\
\hline & XII & 165 & 0,66 & 3,3 & 0,043 & 1,303 & 4,5 & 0,072 & 1,600 \\
\hline & 平 均 & & 0,63 & 4,3 & 0,050 & 1,180 & 4,8 & 0,087 & 1,828 \\
\hline \multirow{4}{*}{6 洔間 } & XIII & 175 & 0,70 & 4,5 & 0,044 & 0,978 & 6,3 & 0,081 & 1,286 \\
\hline & XIV & 145 & 0,58 & 3,5 & 0,035 & 1,000 & 6,0 & 0,063 & 1,050 \\
\hline & $\mathrm{XV}$ & 225 & 0,90 & 4,0 & 0,034 & 0,850 & 6,5 & 0,076 & 1,169 \\
\hline & 平均 & & 0,73 & 4,0 & 0,038 & 0,942 & 6,3 & 0,073 & 1,168 \\
\hline \multirow{4}{*}{8 洔間 } & XVI & 160 & 0,64 & 4,5 & 0,044 & 0,978 & 7,3 & 0,075 & 1,027 \\
\hline & XVII & 135 & 0,54 & 5,0 & 0,043 & 0,860 & 6,3 & 0,061 & 0,968 \\
\hline & XVIII & 135 & 0,54 & 2,2 & 0,017 & 0,773 & 4,5 & 0,052 & 1,156 \\
\hline & 平 均 & & 0,57 & 3,9 & 0,035 & 0,870 & 6,0 & 0,063 & 1,050 \\
\hline \multirow{4}{*}{10 時間 } & XIX & 155 & 0,58 & 5,0 & 0,033 & 0,660 & 5,8 & 0,055 & 0,948 \\
\hline & $\mathrm{XX}$ & 135 & 0,54 & 4,0 & 0,024 & 0,600 & 4,5 & 0,042 & 0,933 \\
\hline & $\mathrm{XXI}$ & 135 & 0,54 & 4,5 & $0,0.34$ & 0,756 & 7,5 & 0,073 & 0,973 \\
\hline & 平 均 & & 0,55 & 4,5 & 0,030 & 0,672 & 6,6 & 0,057 & 0,951 \\
\hline \multirow{4}{*}{24 時間 } & XXII & 120 & 0,48 & 4,0 & 0,017 & 0,425 & 5,0 & 0,049 & 0,980 \\
\hline & XXXII & 135 & 0,54 & 5,0 & 一 & $?$ & 5,5 & 0,046 & 0,836 \\
\hline & XXIV & 180 & 0,72 & 5,5 & - & $?$ & 7,8 & 0,042 & 0,538 \\
\hline & 平 均 & & 0,58 & 4,8 & & & 6,1 & 0,046 & 0,785 \\
\hline
\end{tabular}


酒石酸銅-Natriun $\exists$ 注入シタル場合二於ケル血液中ノ銅量八, 注入後 10 分二於テ 、平均 $3,663 \mathrm{mg}$

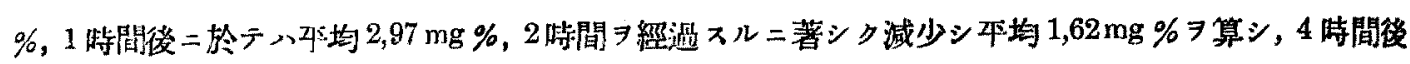

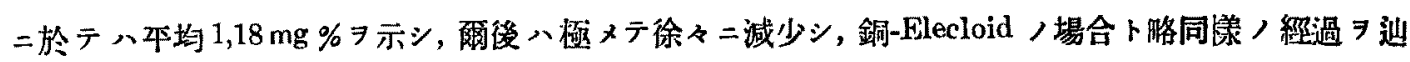
リッッ消失シ，24 時間二至リテ全ク消失スルモノノ如シ。コレニ反シ，肝䁃中ノ銅量八注入後 10 分二 於テ八平均 $0,492 \mathrm{mg} \%, 1$ 時間後二於テ急激二增量シ平均 $2,626 \mathrm{mg} \%$ 示シ, 2 時間啳二於テ平均 2,182 $\mathrm{mg} \%, 4$ 時間後二於テ、平均 $1,828 \mathrm{mg} \% \Rightarrow$ 算出シ，ソノ後八極メテ徐々二消失スルモノノ如シ。

\section{5. 銅-Elecloid 及ビ酒石酸銅-Natrium ヨ家鬼/耳靜胍內二注入シタル後 膽汁中二於ケ几銅ノ排泄並二㺟汁 /生成狀態}

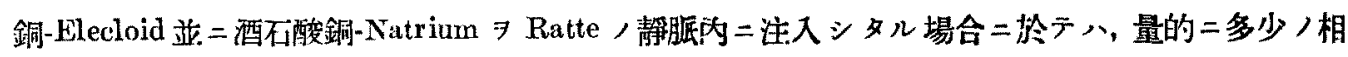

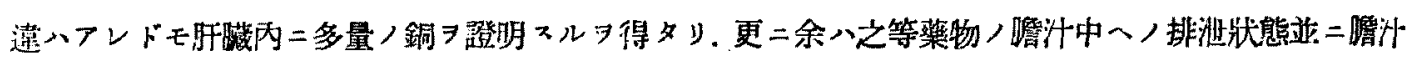

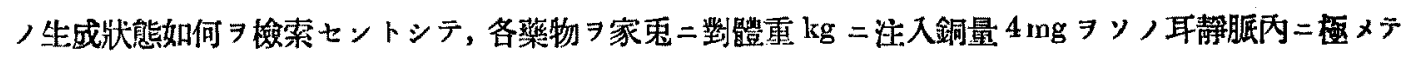

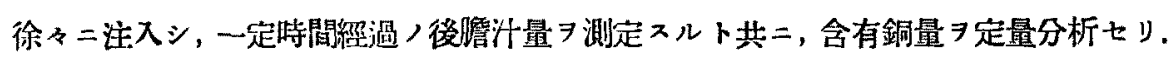

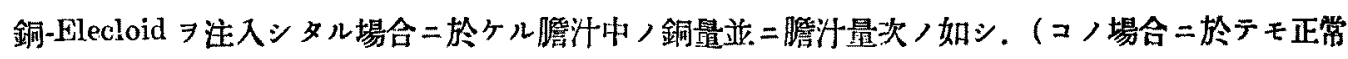
洔二存在スル膽汁中ノ銅量八控除計算七り。)

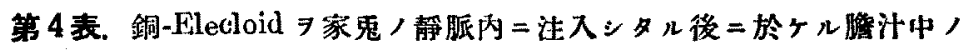
銅含有量 注入銅量對 $\mathrm{kg} 1,6 \mathrm{ccm}$ (含有跼量 $4 \mathrm{mg}$ ).

\begin{tabular}{|c|c|c|c|c|c|c|}
\hline \multirow{2}{*}{$\begin{array}{l}\text {, 注射後， } \\
\text { 縹過特閒 }\end{array}$} & \multirow{2}{*}{ 家鬼/番號 } & \multirow{2}{*}{$\begin{array}{c}\text { 家鬼／體重 } \\
(\mathrm{g})\end{array}$} & \multirow{2}{*}{$\begin{array}{c}\begin{array}{c}\text { 徒 射量 } \\
\text { (對動物) } \\
(\mathrm{ccm})\end{array} \\
\end{array}$} & \multirow[b]{2}{*}{$\begin{array}{l}\text { 释 汁 量 } \\
(\mathrm{ccm})\end{array}$} & \multicolumn{2}{|c|}{ 箈汁中八检出銅量 } \\
\hline & & & & & $\begin{array}{c}\text { 絕 對 量 } \\
(\mathrm{mg})\end{array}$ & $\mathrm{mg} \%$ \\
\hline \multirow{4}{*}{$0-2$ 時間 } & \multirow{3}{*}{$\begin{array}{c}\text { I } \\
\text { II } \\
\text { III }\end{array}$} & 2240 & 3,6 & 6,0 & 0,029 & 0,48 \\
\hline & & 2070 & 3,3 & 8,0 & 0,048 & 0,60 \\
\hline & & 2530 & 4,0 & 13,0 & 0,057 & 0,44 \\
\hline & & & 3,6 & 9,0 & 0,045 & 0,51 \\
\hline \multirow{4}{*}{2 -4 時間 } & \multirow{3}{*}{$\begin{array}{c}\text { I } \\
\text { II } \\
\text { III }\end{array}$} & 2240 & 3,6 & 3,0 & 0,045 & 1,50 \\
\hline & & 2070 & 3,3 & 3,5 & 0,034 & 0,97 \\
\hline & & 2530 & 4,0 & 5,2 & 0,061 & 1,17 \\
\hline & $\mathbb{N}_{=}$ & & 3,6 & 3,9 & 0,047 & 1,21 \\
\hline \multirow{4}{*}{$4-6$ 洔聞 } & \multirow{3}{*}{$\begin{array}{c}I \\
I I \\
I I I\end{array}$} & 2240 & 3,6 & 5,0 & 0,051 & 1,02 \\
\hline & & 2070 & 3,3 & 6,0 & 0,049 & 0,82 \\
\hline & & 2530 & 4,0 & 8,5 & $0, \mathrm{C} 75$ & 0,88 \\
\hline & 均 & & 3,6 & 6,5 & 0,058 & 0,91 \\
\hline \multirow{4}{*}{ 6-8 洔開 } & \multirow{3}{*}{$\begin{array}{c}\text { I } \\
\text { II } \\
\text { III }\end{array}$} & 2240 & 3,6 & 5,5 & 0,050 & 0,91 \\
\hline & & 2070 & 3,3 & 5,0 & 0,042 & 0,84 \\
\hline & & 2530 & 4.0 & 9,0 & 0,064 & 0,71 \\
\hline & 本均 & & 3,6 & 6,5 & 0,052 & 0,82 \\
\hline \multirow{4}{*}{ 8-10 洔閒 } & I & 2240 & 3,6 & 6,0 & 0,049 & 0,82 \\
\hline & II & 2070 & 3,3 & 5,5 & 0,050 & 0,91 \\
\hline & III & 2530 & 4,0 & 13,0 & 0,077 & 0,59 \\
\hline & 诗 & & 3,6 & 8,2 & 0,059 & 0,77 \\
\hline
\end{tabular}




\begin{tabular}{|c|c|c|c|c|c|c|}
\hline \multirow{2}{*}{$\begin{array}{l}\text { 注射後 } \\
\text { 程過時間 }\end{array}$} & \multirow{2}{*}{ 家鬼／番號 } & \multirow[b]{2}{*}{$\begin{array}{c}\text { 家嵬／體重 } \\
\text { (g) }\end{array}$} & \multirow{2}{*}{ 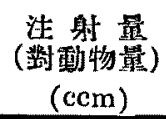 } & \multirow[b]{2}{*}{$\begin{array}{c}\text { 腹汁量 } \\
(\mathrm{ccm})\end{array}$} & \multicolumn{2}{|c|}{ 膽汁中，检出銅器 } \\
\hline & & & & & 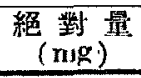 & $\mathrm{mg} \%$ \\
\hline \multirow{4}{*}{$24-26$ 時間 } & IV & 1960 & 3,1 & 6,7 & 0,058 & 0,87 \\
\hline & V & 2340 & 3,7 & 13,0 & 0,067 & 0,52 \\
\hline & VI & 2250 & 3,6 & 13,0 & 0,067 & 0,52 \\
\hline & 均 & & 3,5 & 11,0 & 0,064 & 0,64 \\
\hline \multirow{4}{*}{$48-50$ 時閒 } & VII & 1980 & 3,2 & 18,0 & 0,048 & 0,27 \\
\hline & VIII & 2500 & 4,0 & 12,0 & 0,038 & 0,32 \\
\hline & IX & 2540 & 4,1 & 22,0 & 0,050 & 0,23 \\
\hline & 均 & & $\mathbf{3 , 8}$ & 17,0 & 0,045 & 0,27 \\
\hline \multirow{4}{*}{96 -98 時間 } & $\mathrm{X}$ & 2140 & 3,4 & 13,0 & 0,023 & 0,18 \\
\hline & XI & 2300 & 3,7 & 8,0 & 0,017 & 0,21 \\
\hline & XII & 2500 & 4,0 & 12,0 & 0,018 & 0,15 \\
\hline & 坞 & & 3,7 & 11,0 & 0,019 & 0,18 \\
\hline \multirow{4}{*}{ 144-146 時閒 } & XIII & 2250 & 3,6 & 21,0 & 0,022 & 0,11 \\
\hline & XIV & 2200 & 3,5 & 15,0 & 0,023 & 0,15 \\
\hline & XV & 2500 & 4,0 & 15,0 & 0,013 & 0,09 \\
\hline & 本均 & & 3,7 & 17,0 & 0,019 & 0,12 \\
\hline \multirow{4}{*}{$336-338$ 時間 } & $\mathrm{XVI}$ & 2200 & 3,5 & 16,0 & - & - \\
\hline & XVII & 1920 & 3,1 & 19,0 & 0,006 & 0,04 \\
\hline & XVIII & 2070 & 3,3 & 29,0 & 一 & - \\
\hline & 平均 & & $\mathbf{3 , 3}$ & 21,0 & & \\
\hline
\end{tabular}

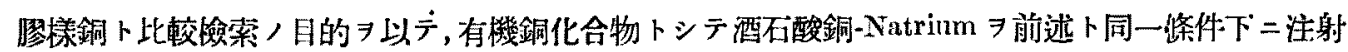
シ，膽汁中ノ銅量及ビ膽汁量 7 測定シタル處, 次ノ如キ成績 7 得タリ。

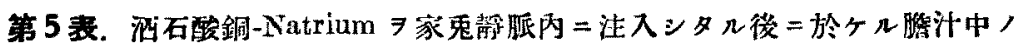
銅含有量 注入銅量對 $\mathrm{kg} 1,6 \mathrm{ccm}$ (含有銅量 $4 \mathrm{mg}$ ).

\begin{tabular}{|c|c|c|c|c|c|c|}
\hline \multirow{2}{*}{$\begin{array}{l}\text { 注射後， } \\
\text { 繹過時間 }\end{array}$} & \multirow[b]{2}{*}{ 家兔／番㩆 } & \multirow[b]{2}{*}{$\begin{array}{c}\text { 家鬼，體重 } \\
(\mathrm{g})\end{array}$} & \multirow{2}{*}{ 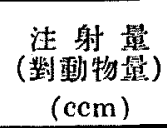 } & \multirow[b]{2}{*}{ 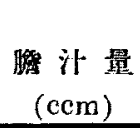 } & \multicolumn{2}{|c|}{ 䁘汁中八檢出洞量 } \\
\hline & & & & & 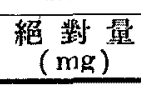 & $\mathrm{mg} \%$ \\
\hline \multirow{4}{*}{0 -2 時閣 } & \multirow{3}{*}{$\begin{array}{c}\text { I } \\
\text { II } \\
\text { III }\end{array}$} & 2225 & 3,6 & 12,5 & 0,044 & 0,35 \\
\hline & & 2480 & 3,9 & 25,0 & 0,055 & 0,22 \\
\hline & & 2300 & 3,7 & 11,0 & 0,040 & 0,36 \\
\hline & 平均 & & 3,7 & 16.2 & 0,046 & $\mathbf{0 , 3 1}$ \\
\hline \multirow{4}{*}{$2-4$ 㭙問 } & \multirow{3}{*}{$\begin{array}{c}\text { I } \\
\text { II } \\
\text { III }\end{array}$} & 2225 & 3,6 & 4,0 & 0,063 & 1,58 \\
\hline & & 2480 & 3,9 & 13,0 & 0,177 & 1,36 \\
\hline & & 2300 & 3,7 & 4,0 & 0,083 & 2,08 \\
\hline & 本均 & & 3,7 & 7,0 & 0,108 & 1,67 \\
\hline \multirow{4}{*}{$4-6$ 洔問 } & \multirow{4}{*}{$\begin{array}{c}\text { I } \\
\text { II } \\
\text { III }\end{array}$} & 2225 & 3,6 & 5,0 & 0,051 & $1,(12$ \\
\hline & & 2480 & 3,9 & 14,5 & 0,134 & 0,92 \\
\hline & & 2300 & 3,7 & 7,5 & 0,110 & 1,47 \\
\hline & & & $\mathbf{3}, 7$ & 9,0 & 0,098 & 1,14 \\
\hline
\end{tabular}




\begin{tabular}{|c|c|c|c|c|c|c|}
\hline \multirow{2}{*}{$\begin{array}{l}\text { 注射箻 } \\
\text { 緭過時問 }\end{array}$} & \multirow{2}{*}{ 家象／番號 } & \multirow[b]{2}{*}{$\begin{array}{c}\text { 家鬼／䜺重 } \\
(\mathrm{g})\end{array}$} & \multirow{2}{*}{$\begin{array}{c}\begin{array}{c}\text { 注 射 量 } \\
\text { (對動物量) } \\
(\mathrm{ccm})\end{array} \\
\end{array}$} & \multirow[b]{2}{*}{$\begin{array}{c}\text { 管 汁 星 } \\
(\mathrm{ccm})\end{array}$} & \multicolumn{2}{|c|}{ 鲘汁中，检出銅量 } \\
\hline & & & & & $\begin{array}{c}\text { 絶 龄 } \\
(\mathrm{mg}) \\
\end{array}$ & $\mathrm{mg} \%$ \\
\hline \multirow{4}{*}{6 -8 時間 } & $I$ & 2225 & 3,6 & 5,0 & 0,026 & 0,52 \\
\hline & II & 2480 & 3,9 & 14,0 & 0,065 & 0,46 \\
\hline & III & 2300 & 3,7 & 12,0 & 0,048 & 0.40 \\
\hline & 本均 & & 3,7 & 10,0 & 0,046 & 0,46 \\
\hline \multirow{4}{*}{8 -10 時間 } & $I$ & 2225 & 3,6 & 7,0 & 0,037 & 0,53 \\
\hline & II & 2480 & 3,9 & 12,0 & 0,038 & 0,32 \\
\hline & III & 2300 & 3,7 & 13,0 & 0,047 & 0,36 \\
\hline & 平均 & & 3,7 & 10,7 & 0,041 & 0,40 \\
\hline \multirow{4}{*}{$24-26$ 時間 } & IV & 2230 & 3,6 & 25,0 & 0,035 & 0,22 \\
\hline & $\mathrm{V}$ & 2200 & 3,5 & 11,0 & 0,037 & 0,34 \\
\hline & VI & 2070 & 3,3 & 12,0 & 0,038 & 0,32 \\
\hline & 平均 & & 3,5 & 16,0 & 0,037 & 0,29 \\
\hline \multirow{4}{*}{$48-50$ 時間 } & VII & 2200 & 3,5 & 15,0 & 0,023 & 0,15 \\
\hline & VIII & 2425 & 3,9 & 12,0 & 0,018 & 0,15 \\
\hline & $I X$ & 2300 & 3,7 & 18,0 & 0,018 & 0,10 \\
\hline & 平 均 & & 3,7 & 15,0 & 0,020 & $\mathbf{0 , 1 3}$ \\
\hline \multirow{4}{*}{98 -98 洔間 } & $\mathrm{X}$ & 2230 & $3, i$ & 15,0 & - & - \\
\hline & $X I$ & 2230 & 3,6 & 21,0 & 0,004 & 0,019 \\
\hline & XII & 1940 & 3,1 & 19,0 & 0,006 & 0,03 \\
\hline & 平均 & & 3,4 & 18,0 & 0,003 & 0,016 \\
\hline
\end{tabular}

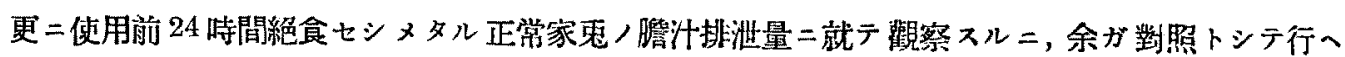

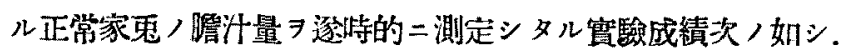

第 6 表. 正常家來，撙外排泄量.

\begin{tabular}{|c|c|c|c|}
\hline $\begin{array}{c}\text { Kanule 抑大後 } \\
\text {,探取時閒 }\end{array}$ & 家鬼 /程就 & $\begin{array}{c}\text { 家鬼，體重 } \\
(g)\end{array}$ & 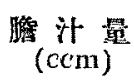 \\
\hline \multirow{4}{*}{$0 \_2$ 時閒 } & I & 2150 & 15 \\
\hline & II & 2200 & 18 \\
\hline & III & 2350 & 24 \\
\hline & 平出 & & 19 \\
\hline \multirow{4}{*}{$2-4$ 時閏 } & I & 2150 & 12 \\
\hline & II & 2200 & 15 \\
\hline & III & 2350 & 19 \\
\hline & 平 & & 15 \\
\hline \multirow{4}{*}{$4-6$ 㻉間 } & I & $2: 50$ & 12 \\
\hline & II & 2200 & 17 \\
\hline & III & $2: 50$ & 18 \\
\hline & 里 & & 16 \\
\hline \multirow{4}{*}{ 6-8 時閂 } & I & 2150 & 14 \\
\hline & II & 22100 & 16 \\
\hline & III & 2350 & 14 \\
\hline & 4 诱 & & 15 \\
\hline \multirow{4}{*}{$8-10$ 特閶 } & I & 2150 & 10 \\
\hline & II & 2200 & 18 \\
\hline & III & 2350 & 15 \\
\hline & 本均 & & 14 \\
\hline
\end{tabular}

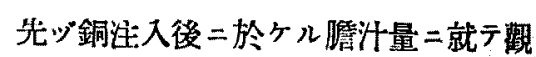
察スルニ, 余ガ對照トシテ行へル 正常家鬼

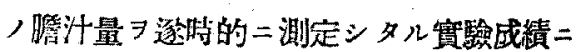
就テ觀儿二(第6 表參照), 正常家鬼 /膽计量

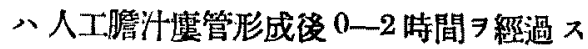
ル 平均 $19 \mathrm{ccm}$ ニシテ, $2-4$ 時間二於テ 八本均 $15 \mathrm{ccm} 7$ 算シ, 4-6 時間 7 經過 $ᄌ$

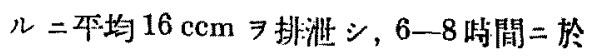
テ、年均 $14 \mathrm{ccm} \Rightarrow$ 算シ, 8-10洔間二於テ

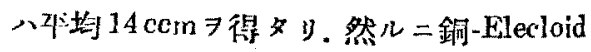
ᄏ注入シタル場合二刅テハ第 4 表二於テ篗 ルガ如ク，0—2喈間二於テ 、东均 $9 \mathrm{ccm}$ ， 脆汁 $\exists$ 排琎スルモ, 2-4 特間 7 經過スル 著シク減少シ平均 $3,9 \mathrm{ccm}, 4-6$ 時間二朎 テハ み゙均 $6,5 \mathrm{ccm}$ ヨ算シ, 6-8 時間二於テ モ平均 $6,5 \mathrm{ccm}=シ テ, 8-10$ 䍶間二於テ 稍增加シ平均 $8,2 \mathrm{ccm}$ 排淮シ, 24-26

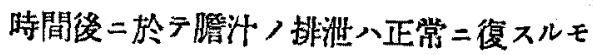




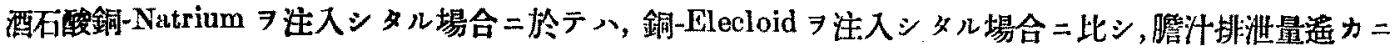
多ク（第 5 表窟照)，0-2 時間二於テハ平均 $16,2 \mathrm{ccm}, 2-4$ 時間二於テハ平均 $7 \mathrm{ccm}, 4-6$ 時間二於テ

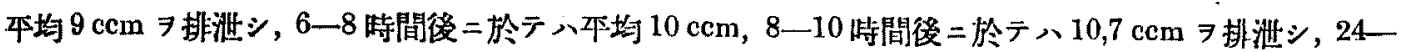

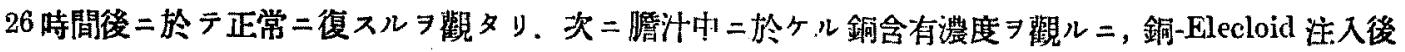

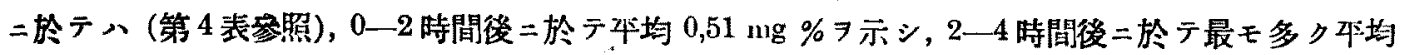
$1,21 \mathrm{mg} \% 7$ 算シ, 爾後八漸次減少シ 4-6 時間後=於テ 八平均 $0,91 \mathrm{mg} \% 7$ 算出シ, 6-8 時間後二於テ

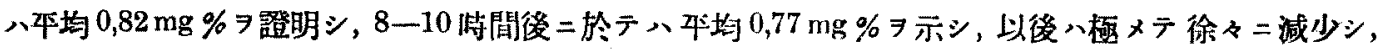
$336-338$ 时間二於テハ 1 例 7 徐クノ外全ク銅习證明スル 7 得ザル:至ル.

次二酒石酸銅-Natrium／場合二於テ，第 5 表二示スガ如ク，本物資注入後 0-2 時間二於テハ4゙均

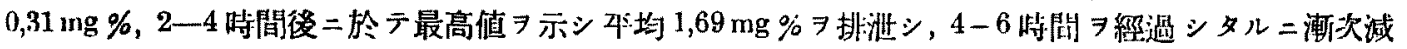

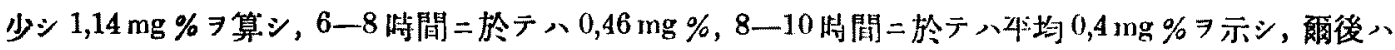
䊀次娍少スルモノノ如シ。

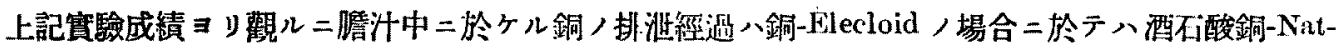

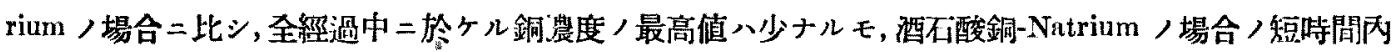

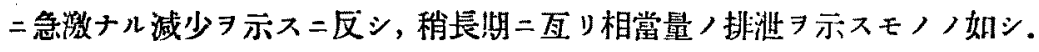

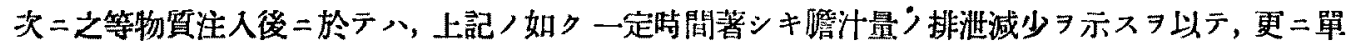

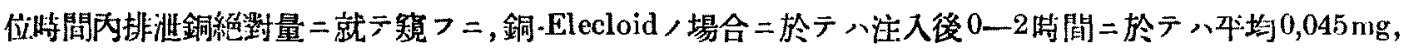
$2-4$ 综間二於テ 、平均 $0,047 \mathrm{ng}, 4-6$ 時間後二八平均 $0,058 \mathrm{mg}, 6-8$ 時閒二於テ 八平均 $0,052 \mathrm{mg}$,

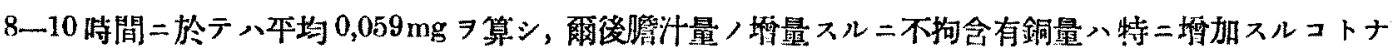
$\eta, 24-26$ 洔間後二於テ八反對二減少ス.

酒石酸銅-Natrium 7 注入シタル場合二於テ八第 5 表ニ示スカ如ク，本物質注入後 $0-2$ 咕間二於テ 八斗均 $0,046 \mathrm{mg}, 2-4$ 時間後二於テ 八平均 $0,108 \mathrm{mg}, 4-6$ 峙間後二於テ 八平均 $0,098 \mathrm{mg}$ 示シ, 6一 8 垨

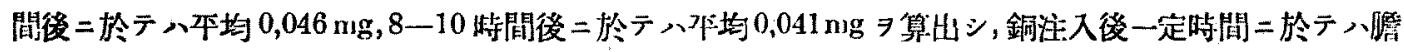

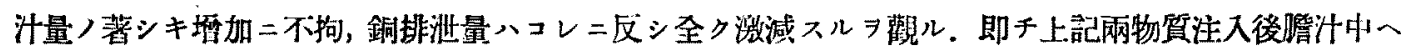

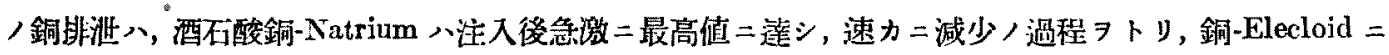
於テ八速カ二最高值二洼スルモ，ソ，值酒不酸銅·Natrium／場合ヨリモ少》，其後比較的徐々二減少， 倾向ヨ示スモノノ如シ.

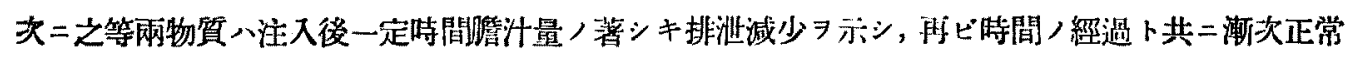

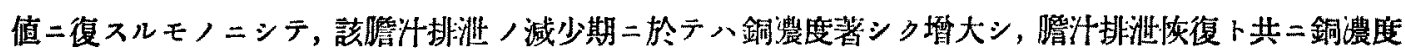

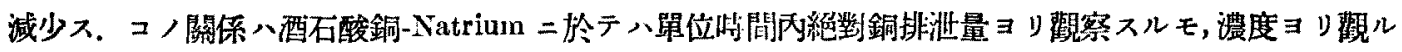

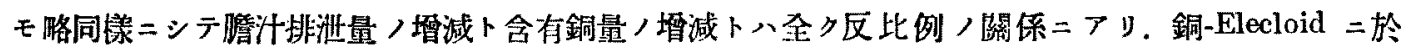

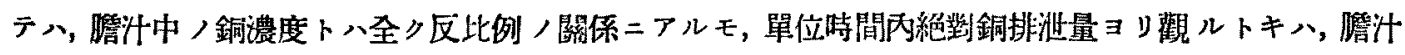
量卜銅排沋量トガ酒石酸銅-Natrium /場合/如ク全ク反比例スルトハ云ヒ得ザルモ,尚銅ノ排泄大ナル

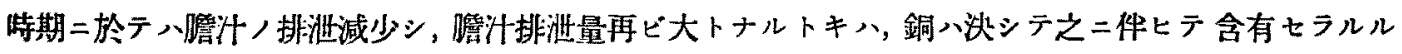
事ナク，却ッテ減少スルモノナルヨ知ルベシ。 


\section{6. 銅-Elecloid 並二酒石酸銅-Natrium 7 家鬼/耳靜胍內 注入シタル後銅ノ尿中二於ケル排泄狀龍}

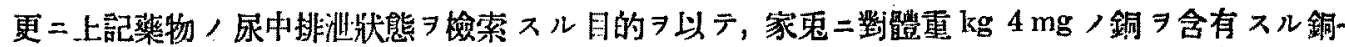

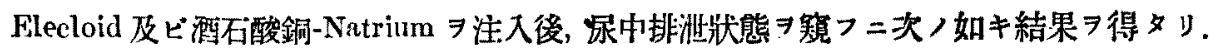

第 7 表. 銅-Flecloid $\Rightarrow$ 家鬼，静脤内二注入シタ几後尿中二於ケ几銅含有量.

（注入銅量䍊體重 $\mathrm{kg} 4 \mathrm{mg}$ )

\begin{tabular}{|c|c|c|c|c|c|c|c|c|c|c|}
\hline \multirow{2}{*}{ 注射後 } & \multirow{2}{*}{\multicolumn{2}{|c|}{$\begin{array}{c}I \\
2050 \\
(\mathrm{~g}) \\
8,2 \\
(\mathrm{ing})\end{array}$}} & \multirow{2}{*}{\multicolumn{2}{|c|}{$\begin{array}{c}\mathrm{JI} \\
2250 \\
(\mathrm{~g}) \\
9 \\
(\mathrm{mg})\end{array}$}} & \multirow{2}{*}{\multicolumn{2}{|c|}{ 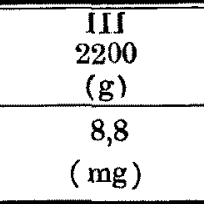 }} & \multirow{2}{*}{\multicolumn{2}{|c|}{$\begin{array}{c}\begin{array}{c}\text { IV } \\
2200 \\
(\mathrm{~g})\end{array} \\
\begin{array}{c}8,8 \\
(\mathrm{rng})\end{array}\end{array}$}} & \multirow{2}{*}{\multicolumn{2}{|c|}{$\begin{array}{c}\mathrm{V} \\
2300 \\
(\mathrm{~g}) \\
9,2 \\
(\mathrm{Ing})\end{array}$}} \\
\hline & & & & & & & & & & \\
\hline & $\begin{array}{l}\text { 尿量 } \\
\text { (ccm) }\end{array}$ & $\begin{array}{l}\text { 銅量 } \\
\text { (mg) }\end{array}$ & $\begin{array}{l}\text { 尿量 } \\
(\mathrm{ccm})\end{array}$ & $\begin{array}{l}\text { 銅量 } \\
(\mathrm{mg})\end{array}$ & $\begin{array}{l}\text { 尿量 } \\
(\mathrm{ccm})\end{array}$ & $\begin{array}{l}\text { 銅量 } \\
(\mathrm{mg})\end{array}$ & $\begin{array}{l}\text { 尿量 } \\
(\mathrm{ccm})\end{array}$ & $\begin{array}{l}\text { 銅量 } \\
(\mathrm{mg})\end{array}$ & $\begin{array}{l}\text { 尿量 } \\
(\mathrm{ccm})\end{array}$ & $\begin{array}{l}\text { 銅量 } \\
\text { (mg) }\end{array}$ \\
\hline 6 洔閒 & 48 & $t$ & 15 & \pm & 27 & + & 77 & $H$ & 50 & + \\
\hline 1 日 & 20 & $H$ & 15 & + & 10 & \pm & 140 & 0,25 & 25 & + \\
\hline 2 日 & 20 & \pm & 14 & - & 28 & + & 38 & + & 40 & \pm \\
\hline 3 日 & 49 & + & 33 & \pm & 10 & 土 & 65 & 0,03 & 65 & $H$ \\
\hline 4 日 & 15 & - & 18 & - & 10 & \pm & 77 & + & 120 & + \\
\hline 5 日 & 17 & - & 16 & - & 14 & - & 死 & こ & 50 & \pm \\
\hline 6 日 & 35 & - & & & 35 & \pm & & & 50 & \pm \\
\hline 8 日 & 40 & - & & & 40 & - & & & 45 & - \\
\hline
\end{tabular}

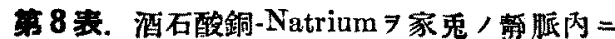
注入シタ几後尿中二於ヶ儿銅含有量 （注入銅量對體重 $\mathrm{kg} 4 \mathrm{mg}$ )

\begin{tabular}{|c|c|c|c|c|c|c|}
\hline 家鬼番號 & \multicolumn{2}{|c|}{$\begin{array}{c}\mathrm{I} \\
2540 \\
(\mathrm{~g})\end{array}$} & \multicolumn{2}{|c|}{$\begin{array}{c}\text { II } \\
2650 \\
(\mathrm{~g})\end{array}$} & \multicolumn{2}{|c|}{$\begin{array}{l}\operatorname{Irr} \\
2250 \\
(\mathrm{~g})\end{array}$} \\
\hline 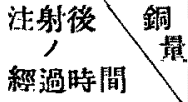 & \multicolumn{2}{|c|}{$\begin{array}{l}10,16 \\
(\mathrm{mg})\end{array}$} & \multicolumn{2}{|c|}{$\begin{array}{l}10,60 \\
(m g)\end{array}$} & \multicolumn{2}{|c|}{$\begin{array}{c}9,0 \\
\text { (mg) }\end{array}$} \\
\hline & $\begin{array}{l}\text { 尿量 } \\
\text { (ccru) }\end{array}$ & ( & $\begin{array}{l}\text { 尿量 } \\
(\mathrm{ccm}\end{array}$ & $\begin{array}{l}\text { 銅量 } \\
(\mathrm{mg})\end{array}$ & $\begin{array}{l}\text { 尿量 } \\
\text { (ccm }\end{array}$ & $\begin{array}{l}\text { 銅量 } \\
(\mathrm{mg})\end{array}$ \\
\hline 6 時閶 & 53 & 0,03 & 37 & + & 19 & + \\
\hline 24 時間 & 15 & + & 47 & 0,05 & 24 & 0,02 \\
\hline 2 日 & 20 & + & 190 & 0,09 & 33 & + \\
\hline 3 日 & 94 & $H$ & 53 & + & 52 & H \\
\hline 4 月 & 28 & + & 22 & + & 27 & + \\
\hline 5 日 & 30 & 一 & 25 & - & 35 & - \\
\hline 6 日 & 22 & - & 14 & - & 20 & - \\
\hline
\end{tabular}

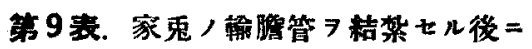
於テ銅-Flecloid 7 脈內 =注入ע 夕几後沓中，銅含有量-(注入銅量 墨娟重 $\mathrm{kg} 4 \mathrm{mg}$ )

\begin{tabular}{|c|c|c|c|}
\hline 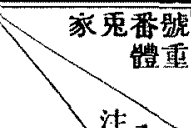 & \multirow{2}{*}{$\begin{array}{c}\begin{array}{c}\mathrm{I} \\
2200 \\
(\mathrm{~g})\end{array} \\
\begin{array}{c}8,8 \\
(\mathrm{mg})\end{array}\end{array}$} & \multirow{2}{*}{\multicolumn{2}{|c|}{$\begin{array}{c}\begin{array}{c}\text { II } \\
2300 \\
(\mathrm{~g})\end{array} \\
\begin{array}{c}9,2 \\
(\mathrm{mg})\end{array}\end{array}$}} \\
\hline $\begin{array}{l}\text { 注射後 } \\
\text { 銅 } \\
\text { 經過時間 }\end{array}$ & & & \\
\hline & $\begin{array}{l}\text { 尿最 銅量 } \\
(\mathrm{ccm})(\mathrm{mg})\end{array}$ & $\begin{array}{l}\text { 尿量 } \\
(\mathrm{ccm})\end{array}$ & $\begin{array}{l}\text { 銅量 } \\
(\mathrm{mg})\end{array}$ \\
\hline 24 時開 & $37 \quad 0,25$ & 42 & 0,1 \\
\hline 2 日 & 0,08 & 80 & 0,15 \\
\hline 3 日 & + & 83 & 0,12 \\
\hline 4 日 & 0,04 & 63 & 0,1 \\
\hline 5 日 & - & 68 & 0,08 \\
\hline 7 日 & 0,05 & 45 & 0,05 \\
\hline 14 日 & 死亡 & 15 & + \\
\hline
\end{tabular}


銅-Elecloid 注入後尿中ノ銅排泄八(第 7 表參照)，第 1 例二於テハ、注入後第 3 日日迄八陽性ナリシ

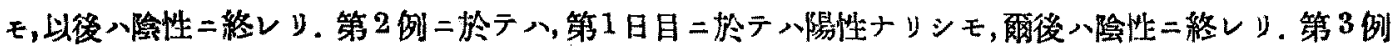
二於テハ, 第2 日目迄八陽性二認义得タルモ，第 5 日目八跨性ニシテ，第 3 , 第 4 , 第 6 日目二於テ八痕 跡二證明セシモ以後入㱠ド認入得ザリキ. 第 4 例二於テハ, 注入後第 4 日目迄八陽性ナリシモ，第 5 日 目二於テ死亡セリ。第 5 例八注入以後第 6 日目迄八陽性或八痕跡二認火得タルモ, 以後濑次陰性二終レ ข.

酒石酸銅-Natrium 7 注入シタル場合二於ヶル尿中ノ銅ノ排泄牀態、(第 8 表參照)，第 1 例二於テ 八注入後第 4 日目迄八陽性ナリシ，以後、险性ニ終レリ. 第 2 例二於テハ注入後第 3 日日迄八陽性ナリ シモ第 4 日目八痕跡二福明シ以後入陰性二終レリ。第 3 例又第 2 例二同ジ.

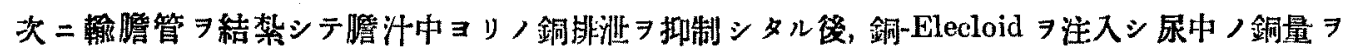

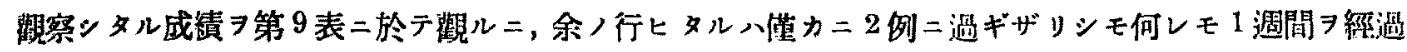
スルモ份腚量的二銅习澄明スル

\section{總括及ビ考察}

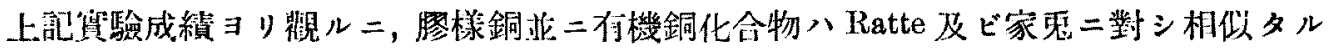

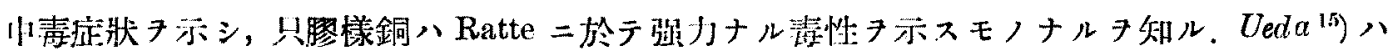

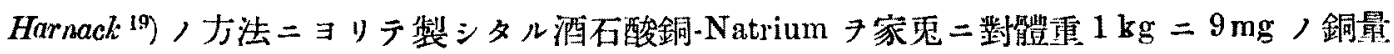

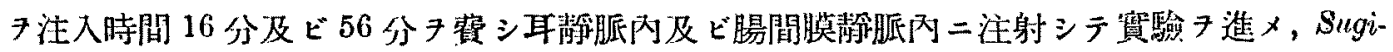

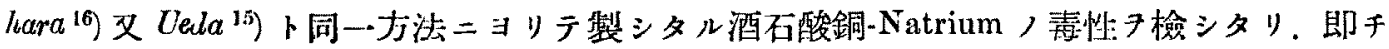

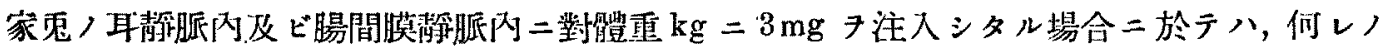

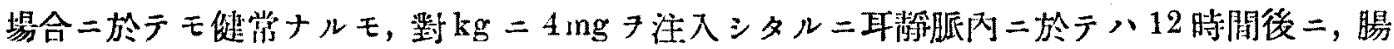
間膜靜脈內二於テハ16 時間後二死亡シ, 對 $\mathrm{kg} 5 \mathrm{mg} 7$ 耳静脈內二注入シタル場合二於テハ,

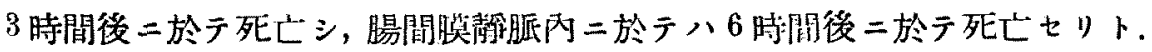

次二動物體內二自然二存在スル銅量ハソノ地方或ハ國士ノ士壤中二存在スル銅含盾

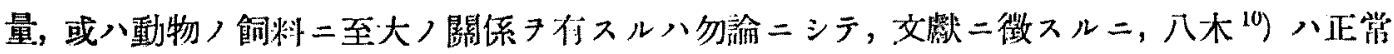
家鬼肝藏中ノ銅量ハ $0,5159 \mathrm{mg} \%$, 售汁中ノ銅念化量ハ $0,5 \mathrm{mg} \%$ ナルモ脆汁中ノ銅量八銅 尹經口的二投與シタル場合二於テハ却ッテ銅量娍少セりト．然レド脆汁ハ濃淡常ナラザ

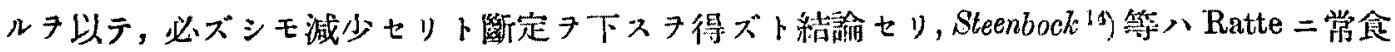
尹投與シタル場合二於々ル血液中，銅含有量ハ $0,0543 \mathrm{mg} \%$ 肝藏中二於テハ $0,584 \mathrm{mg} \%$

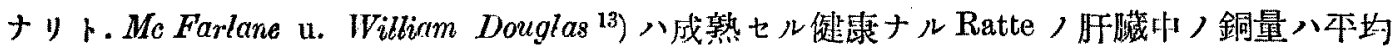

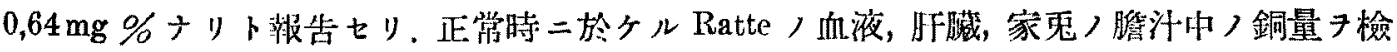

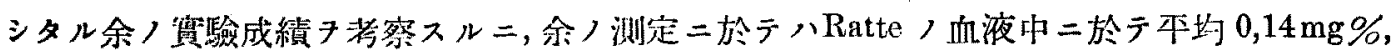

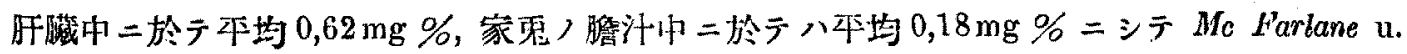

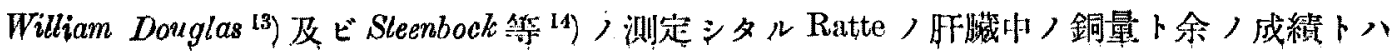


相一政スルモ, Steenbock 等州) 测定シタルRatte /血液山二含有スル銅量ト余ノ成績トハ

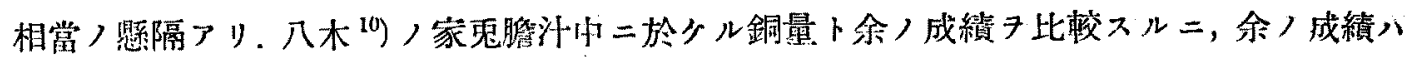
八木 ${ }^{10}$ ) ソレニ比シ少手 7 䚋タり。

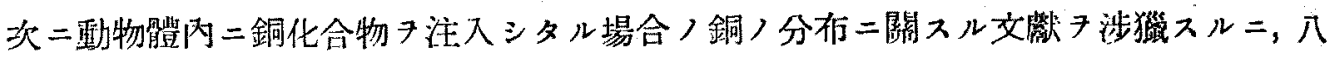

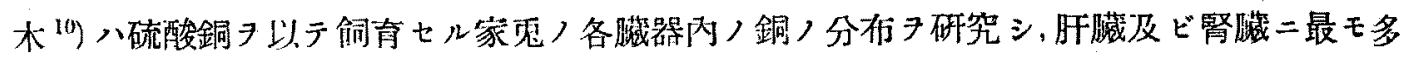
ク發明セりト報告シ, Flinn u. Inoue ${ }^{17}$ ) 八銅, 錫, 亞鉛, Aluminium, Nickel 7 以テ飼育セル

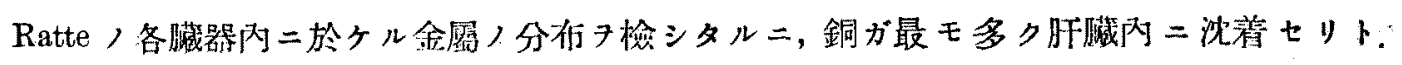

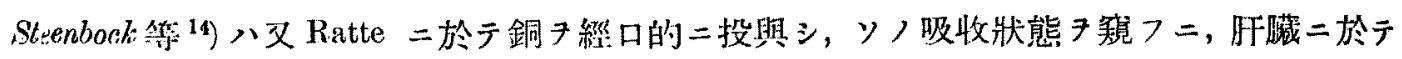

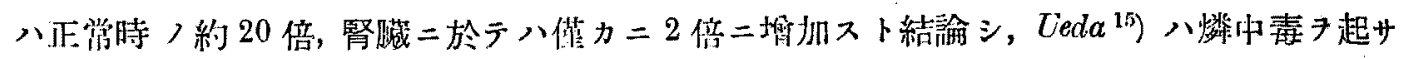

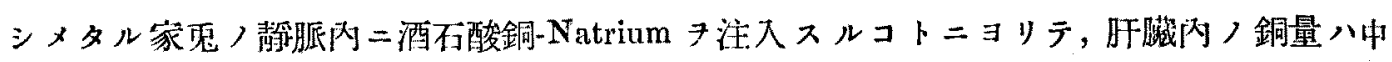

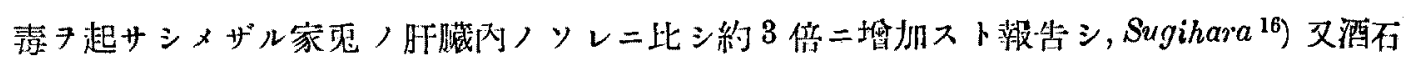

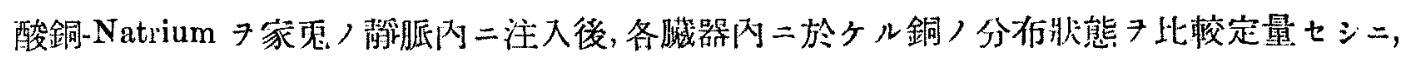

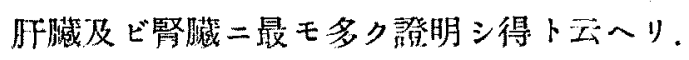

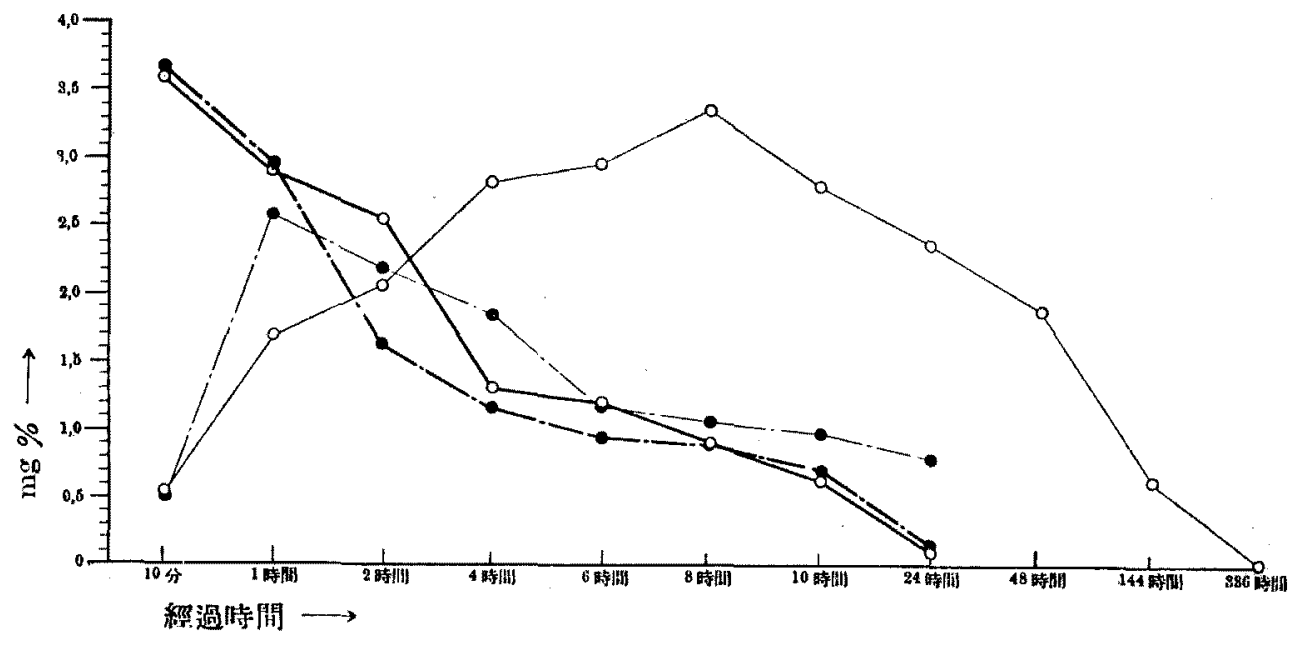

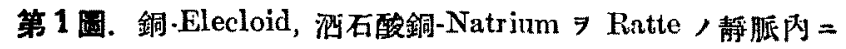

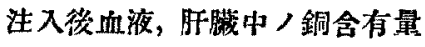

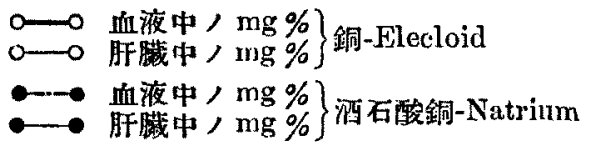

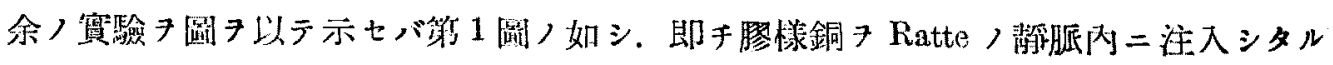
場合二於ケル血液中ノ銅量》, 注入後 4 時間二至ル迄》減少經過急激ニシテ，コノ時期二

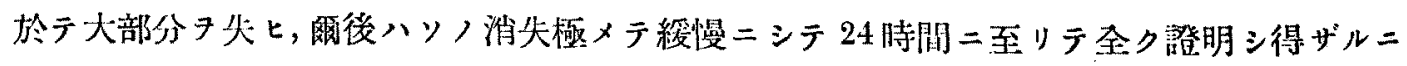

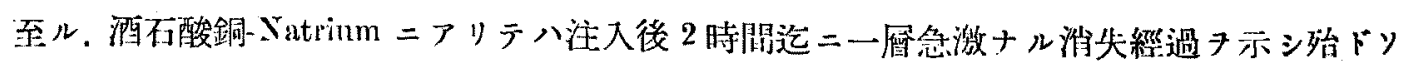

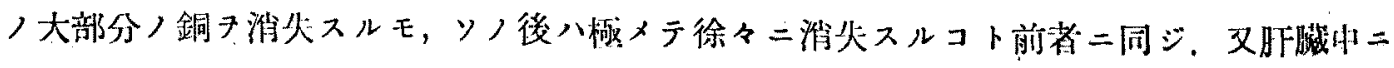


於ケル銅量ハ, 前者ニアリテハ测定最初ノ洔間即手 10 分ヨリ潮次階段狀二上昇シ， 8 時間 後二於テ最モ多量二證明セラレタル銅量ハ, 其後極メラ徐々二減少シ, 336 時間後二於テ㫊 ト證明セラレザルニ至ル，コレニ反シ，後者ニアリテ八注入後 1 時間二於テ最モ多ク銅子 證明シ, 爾後ハソノ消失綬慢ナルモ 24 時間後二於テ八極メテ微量二登明セラル、ノミトナ ル.

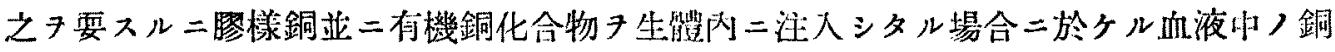
量)多家ニ至リテハ, 注入後, 檢索時間ニヨリテ異ナル所大ニシテ, 文膠樣銅ト有機銅化

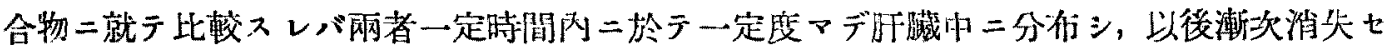

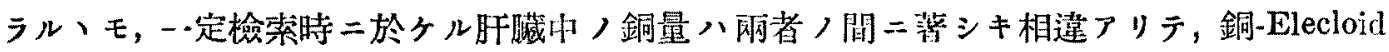

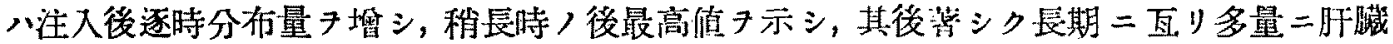
中二殘留スルモノナルチ知ル，酒石酸銅-Natrium，注入後短時間內二最高度二分布シ，後 直チ二減少二傾キ，旰贓中二多量二殘留スル時閶八前者二此シ著シク短キモノ、如シ。

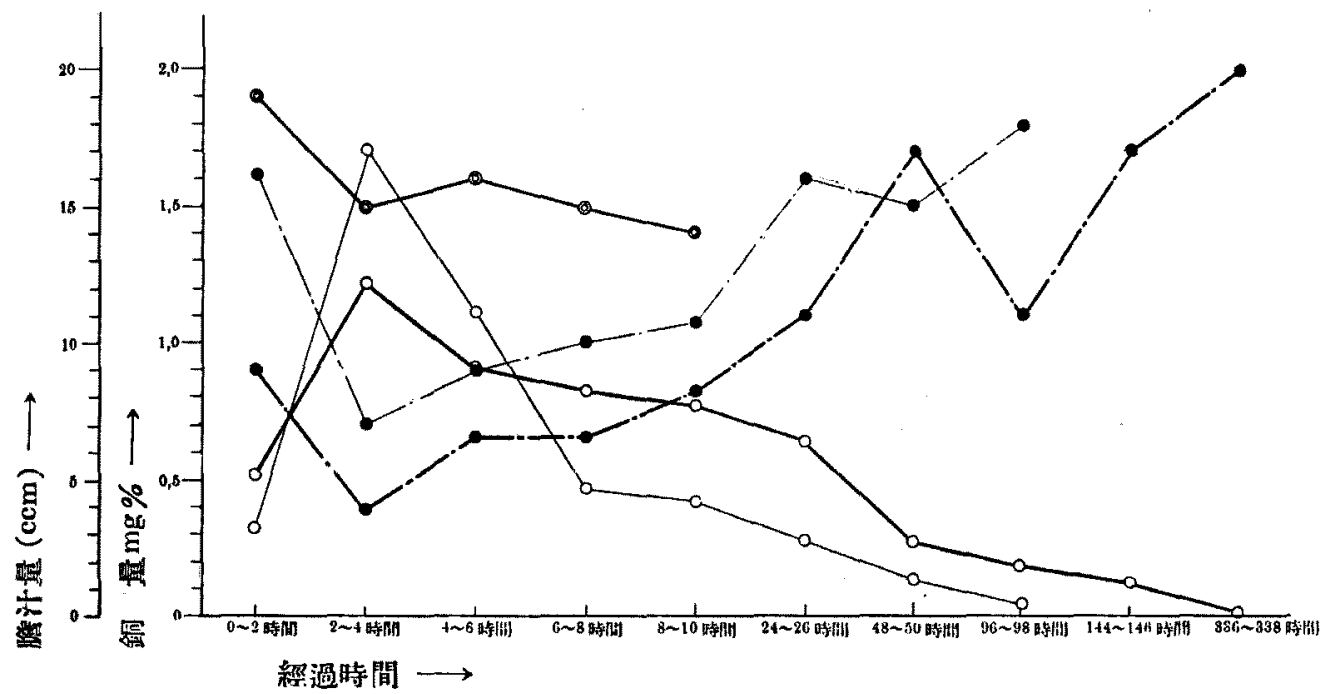

第 2 圆. 銅-Elecloid, 酒石酸銅-Natrium 7 家鬼 / 静胙队二 注入後嚕汁中八銅合有量.

0 瞧汁中，銅量 (銅-Elecloid),

○一䁔汁中八銅量 (酒石酸銅-Natrium),

$\bullet \rightarrow$ 路计量 (䞒-Elecloid),

$\bullet$ - 睢汁量 (酒石酸銅-Natrium).

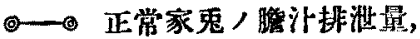



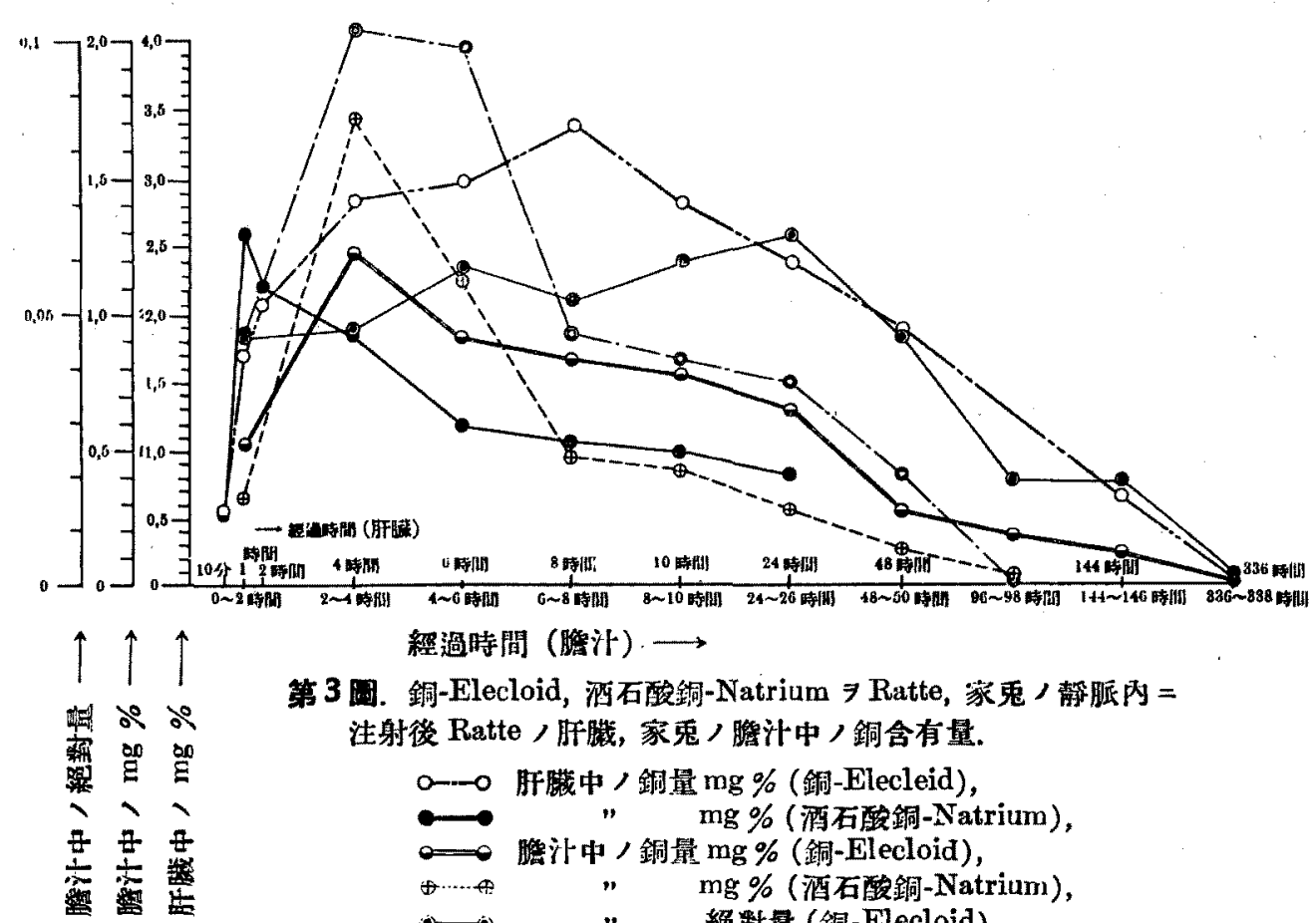

䋚過時間(脆计) - $\longrightarrow$

第 3 圆. 銅-Elecloid, 酒石酸銅-Natrium $\Rightarrow$ Ratte, 家鬼一静脈內 $=$

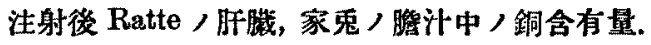

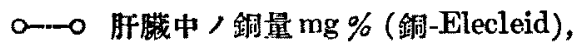

$$
\begin{aligned}
& \longrightarrow \quad \text { mg \% (酒石酸銅-Natrium), } \\
& \text { ○朖汒中/銅量 } \mathrm{mg} \% \text { (哂-Elecloid), } \\
& \text { +... } \quad \mathrm{mg} \% \text { (酒石酸銅-Natrium), }
\end{aligned}
$$

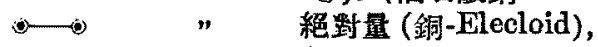

$$
\begin{aligned}
& \text { ○一絕對量 (酒石酸䞒-Natrium). }
\end{aligned}
$$

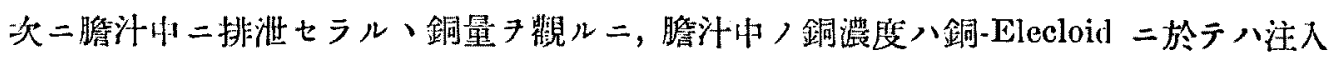
後 2-4 時間二於テ最大值二澾シ, 8-10 時間二至ルモ份且比较的多量二證明セラレ, 殘留 量八極メテ徐々二減少ノ過程タトリ，全ク銅ノ排泄フ證明シ得ザルニ至ルニハ大約 2 週間 ヨ要スルモ，、如シ. 酒石酸銅-Natrium ニ於テハ2-4 㭙閒二於テ最大値二達シ, ソノ值八 銅-Elecloid 二比シ遥カ二大ナルモ,ソノ後急激二排泄セラレ,96時間後二於テハ多ド銅排 泄き證明セザルニ至ル。

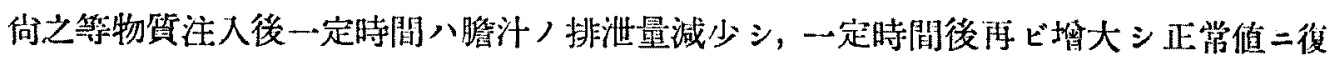

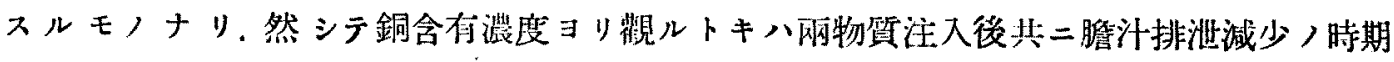

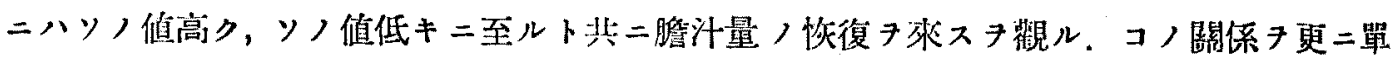

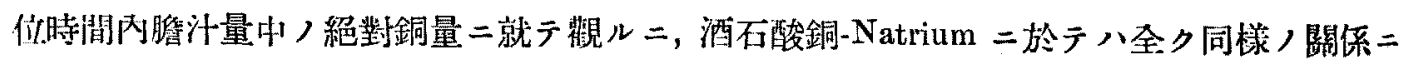

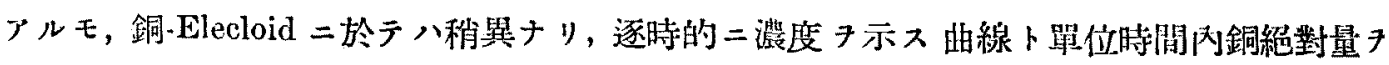
宗ス曲線トハ平行七ザルモノアレドモ，何此ノ場合二於テモ膽汁中へ，銅，排泄最モ盛ナ

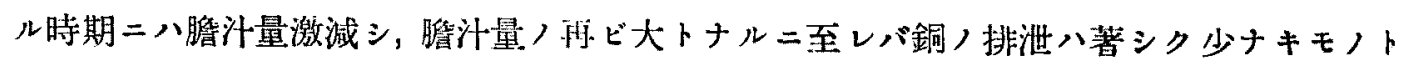
ナルハ明カニシテ，存機銅化合物卜相似タル關係ニアルモノナルタ知ルナ得べシ.

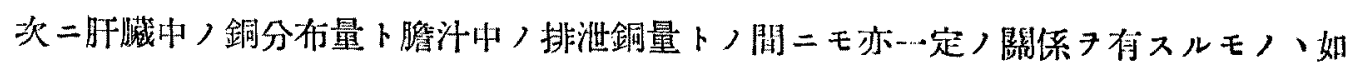

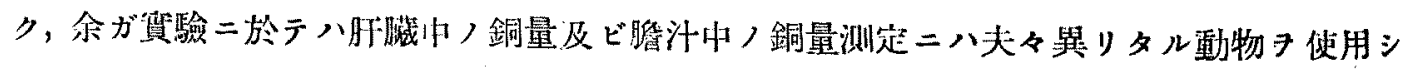

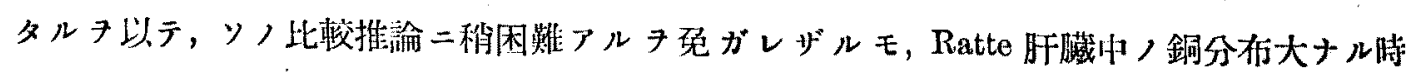




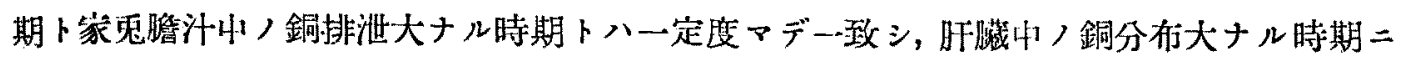

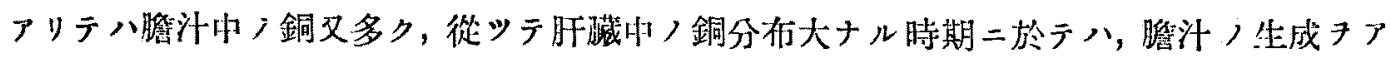
ル程度マデ抑㸝セラル、モノアルタ想像セシム．換言スレバ肝㶓中.)銅分柞大ナル時期二

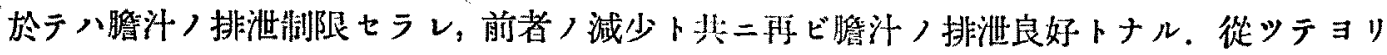
長ク旰臟中二銅ノ多量二分布セラル、銅-Elecloid，注入後二於ラハ, 酒石酸銅-Natrium，

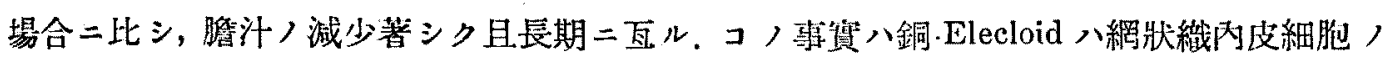

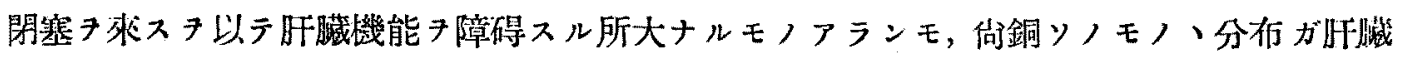
ノ機能二對シ著シキ影響アルフ肯シムルモノナリ。

兩者ノ尿中排泄ハ極メテ徽量ニシテ定量的二證明シ得ラレザルタ以テ量的相違二關シ テハ論ジ難キモ，前者二比シ後者ノ排泄良好ナルタ想ハシム．更二輸膽管タ結㷊シタル後

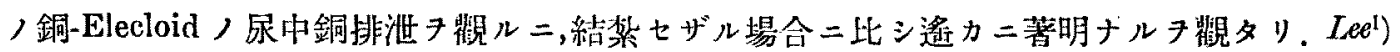

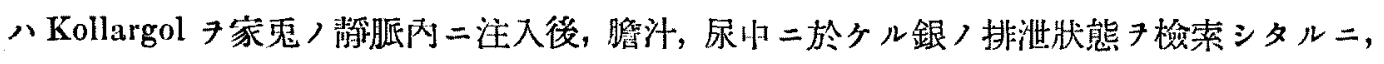

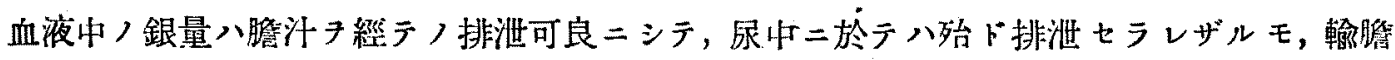

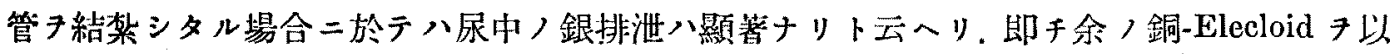
テシタル結果モ亦 $L e e^{1}$ )ト相一致スルタ睍タリ。

\section{結}

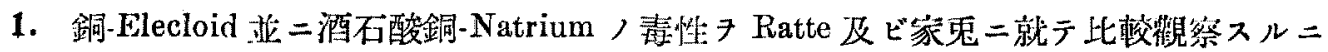
丽者トモ二相似タル中毒淀狀 ヨ示スモ, 銅-Elecloid，後者二比シ Ratte二於テ稍强力ナル 皘性:タ示スガ如シ.

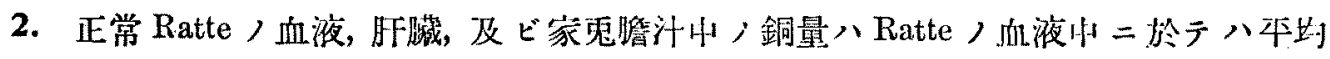

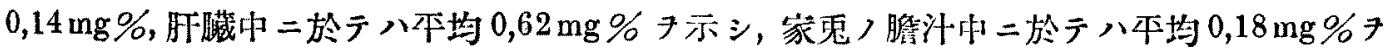
䪭明スルフ得タリ。

3. 銅-Elecloid亚二酒石酸銅-Natrium 7 Ratte $/$ 塪脈內二注入シタル場合二於ヶル血 液中ノ銅量八, 前省ニアリテハ注入後 4 時間队二於テソノ大部分 7 消失スルモ，其後徐 二消失シ，24 時間二於テ咍ド證明セラレザル二至リ，後者ニアリテハ注入後 2 時間二於テ ソノ大部分 7消尖シ，其後徐々二消火七ラル、コトハ前者二似タリ．朋藏中ノ銅量八銅Elecloid 7注入シタル場合二於テハ時间ノ經過ト其二階段狀二上开シ, 注入後 8 時間二於 テ最モ多ク證明セラレ，其後ノ消失極メテ緩慢ナルニ区シ，酒石酸銅-Natrium ニアリテハ，

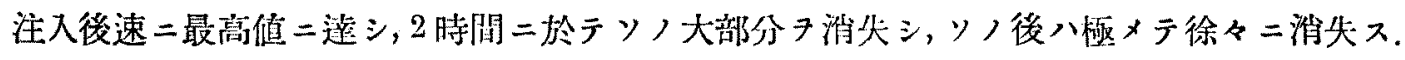

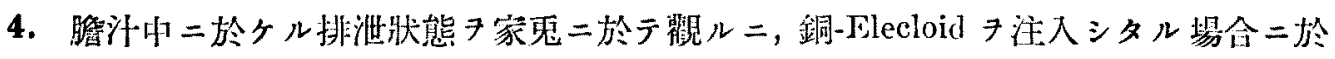
テハ、腯汁中ノ銅濃度ヨリ覞レバ注入後 2-4時闸二於テ最モ大量二排泄セラル、モ,ソノ 後ノ排泄八極メテ䌊慢ナルニ反シ, 酒石酸銅-Natrium ニアリテハ注入後 2 -6 時間二於テ 
ソノ大部分ヨ排泄シ，爾後ハ極メテ徐々二排泄セラル。

5. 上記丽物質注入後ニ於テハー・定時間脆汁 ノ排泄师限七ラレ, 其後一定時間經過後

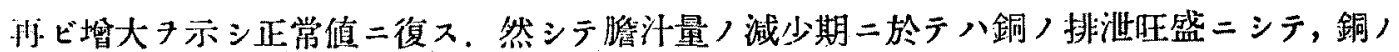

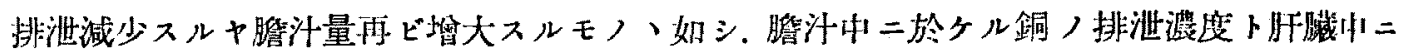

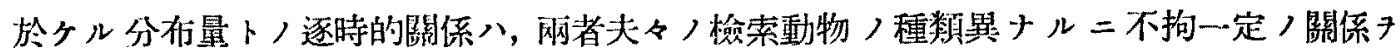
传入.

6. 兩者ノ尿中排泄八極メテ微量ナルモ, 銅-Elecloid 二比シ酒石酸銅-Natrium ノ排泄

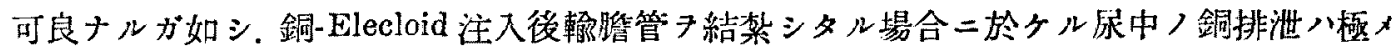
テ顯著ナルフ認メタリ。

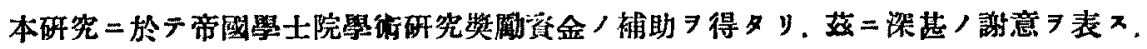

\section{引用音目}

1) Lee : Folia pharmacol. japon. 22, 1 (1935).

2) Buchhollz u. Meissner: Zit. n. K. B. Lehmann, Arch. f. Hyg. 24, 18 (1895).

3) Oolvell: Journ. of Physiol. 39, 358 (1909).

4) Meyerhof u. Matsuoka: Biochem. Zeitschr. 150, 1 (1924).

5) Severy u. Hazel: Jour. of biol. Chem. 56, 79 (1923).

6) Krebs: Biochem. Zeitschr. 180, 377 (1927).

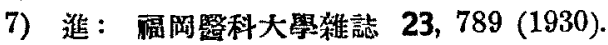

8) Sarzeau: Zit. n. K. B. Lehmann, Arch, f. Ḧyg. 24, 18 (1895).

9) Lehmann: Arch. f. Hyg. 24.18 (1895).

10) 八木：宗都繁學誰誌 6, 123 (1909).

11) Schönheimer u. Osehima: Hoppe-Seyler's Zeitschr. 180, 249 (1929).

12) Tompsett u. Sidney Lionel: Biol. J. 28, 1544 (1934).

13) Mc. Farlane u. William Douglas: Ibid. 26, 1022 (1932).

14) Lindow, C,W., W, H, Peterson u. H. Steenbock: Journ. of biol. Chem. 84, 419, (1929).

15) Ueda: Acta Scholae med. Kioto 7, 481 (1925).

16) Sugihara: Ibid 7, 491 (1925).

17) Fiinn u. Inoue: Journ. of. amer. med. Assoc. 90, 1010 (1928).

18) Harnack: Arch. f. exp. Path. u. Pharmakol. 3, 44 (1875).

19) Lehmann: Arch. f. Hyg. 24, 1 (1895). 